\title{
Ewa Bogula
}

UNIWERSYTET WARSZAWSKI

\section{Joseph Woelf1 ${ }^{1}$ - życie i działalność artystyczna}

\section{Abstract \\ Joseph Woelfl - Life and Artistic Activity}

The present article constitutes an introduction to the artistic profile of Austrian composer and piano virtuoso Joseph Woelfl. This forgotten creative personality left an artistic legacy of instrumental music, stage works, numerous orchestral compositions, piano concertos, a concerto for piano and violin, and a chamber concerto. Beyond this, he wrote numerous other chamber works scored for various ensembles; but above all, he created an array of works for solo piano or two pianos, as well as piano pieces of pedagogical character.

1 W niniejszej pracy przyjęłam taką wersję pisowni nazwiska, jaką od 1793 roku stosował sam twórca. Najwcześniejszy znany dokument $\mathrm{z}$ jego podpisem $\mathrm{w}$ wersji „Joseph Woelfl” odnajdujemy w zmiankowanej w dalszej części niniejszego artykułu prośbie o zgodę na koncert publiczny 9 listopada 1793 roku w Teatrze Grodzieńskim. Nazwisko członków rodziny stosuję natomiast w pierwotnym brzmieniu, tj. Wölfl. W literaturze występuje ono także błędnie w innych wariantach - Wölffl oraz Woelffl. 
The artist was born on 24 December 1773 in Salzburg, where he began his musical education. In 1790, he left his hometown of Salzburg and, probably following in Wolfgang Amadeus Mozart's footsteps, set out for Vienna. He did not remain there long, however, because in 1791, he was accepted for service to Prince Michał Kleofas Ogiński in Warsaw. The pianistcomposer returned to Vienna probably ca 1795 . He set out on his next conquest of European cities in 1799. This period of tours lasted until 1801. At this time he visited, among other cities, Prague, Leipzig, Berlin, Hamburg and Dresden. In 1801, he arrived in Paris, where he spent the next four years of his life. In 1805, he left the French capital and set out for London, where he remained until his death. He passed away on 21 May 1812.

In his intensive artistic career, Joseph Woelf devoted himself mainly to piano performance and composition; beyond this, he also engaged in pedagogical activity. His abundant artistic output is nearly forgotten today, so it is worthwhile to remind a broader audience of this distinguished figure.

\section{Keywords}

Joseph Woelfl, piano, virtuosity, brillant style, Salzburg, Vienna, Warsaw, Paris, London

\section{Lata młodzieńcze w Salzburgu (1773-1791)}

Johann Paul Wölfl - ojciec Josepha Woelfla - pochodził z ubogiej rodziny szlacheckiej. Ukończył studia prawnicze, a w 1769 roku otrzymał posadę w służbie księcia arcybiskupa Salzburga Sigismunda III von Schrattenbacha jako dyrektor kawalerii i uznawany był za najzdolniejszego, choć najmłodszego na swym stanowisku urzędnika dworu. Rok później, w 1770, został awansowany i otrzymał posadę „superrevisionsupernumerarius"2 (księgowego), a po przejęciu władzy przez nowego arcybiskupa księcia Hieronymusa Josepha Colloreda została mu przekazana ważniejsza posada poborcy podatkowego - „Hofumgelter”3. W konsekwencji objęcia wyższego stanowiska Johann Paul Wölfl otrzymał służbowe mieszkanie w klasztorze św. Piotra, w którym to budynku

2 M. Haider-Dechant, Joseph Woelfl. Verzeichnis seiner Werke, Wien 2011, s. XVIII.

3 Tamże. 
mieszkał również Michael Haydn, pełniący wówczas funkcję organisty dworskiego oraz koncertmistrza arcybiskupa Colloreda ${ }^{4} .3$ listopada 1770 roku Johann Paul Wölfl poślubił Theresię von Sechzern z domu Preusin, wdowę po Johannie Bernhardzie von Sechzernie. Richard Baum w swojej wydanej w 1928 roku biografii Josepha Woelfla podaje, że mieszkanie rodziny Wölflów znajdowało się prawdopodobnie nad mieszkaniem Michaela Haydna oraz że właśnie tutaj 24 grudnia 1773 roku o godzinie 10:30 przyszedł na świat Joseph Johann Baptist Woelfl ${ }^{5}$.

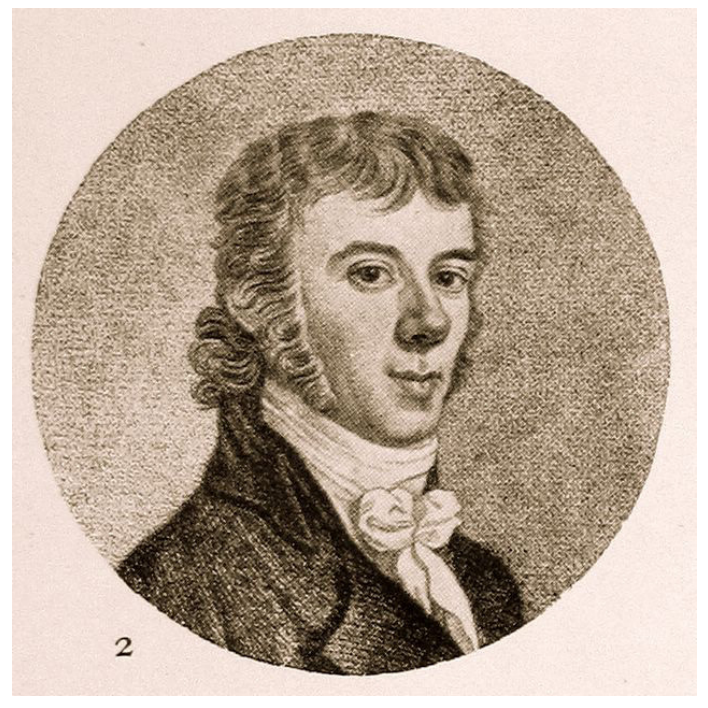

Ilustracja 1. Johann Gottfried Scheffner, Joseph Woelfl, rycina na podstawie obrazu Friedricha von Amerlinga.

Nie jest do końca wiadome, ile lat miał Joseph Woelfl, gdy rozpoczął swoją muzyczną edukację. Badacze zajmujący się biografią kompozytora, w tym Margit Haider-Dechant, podają, że w wieku siedmiu lat wystąpił już jako skrzypek, i to podczas publicznego koncertu'. Interesujące jest więc, że przyszły kompozytor rozpoczął karierę od gry na skrzypcach, lecz instrument ten - jak wskazują dalsze losy twórcy - nie znalazł się nigdy w centrum jego muzycznych zainteresowań.

4 Tamże.

5 R. Baum, Joseph Wölfl (1773-1812). Leben, Klavierwerke, Klavierkammermusik und Klavierkonzerte, Kassel 1928, s. 8.

6 M. Haider-Dechant, dz. cyt., s. XVIII. 
W każdym razie naukę gry rozpocząć musiał dużo wcześniej. Posiadamy także informacje, że dziesięcioletni Joseph był uczniem szkoły muzycznej Kapellhaus, która utrzymywana była przez arcybiskupa Salzburga. Szkoła ta zatrudniała najwybitniejszych działających wówczas w mieście muzyków. W Kapellhaus kształcono młodzież w zakresie śpiewu chorałowego i figuralnego, nauczano gry na skrzypcach, klawesynie oraz organach. W szkole kładziono także nacisk na ogólne wykształcenie uczniów oraz przywiązywano wagę do ich religijnej postawy. Dbano ponadto o przyszłość uczniów - za służbę w kościołach byli oni dodatkowo wynagradzani, a zarabiane przez nich pieniądze odkładano w postaci lokaty przekazywanej uczniowi, gdy ten opuszczał mury szkoły. W latach 1783-1786, kiedy młody Woelfl uczęszczał na lekcje muzyki do Kapellhaus, wśród nauczycieli tam wykładających znajdowali się: Thaddäus Hofmann, zajmujący stanowisko wikariusza chóru w latach 1780-1806; tenor Karl Schulz, nauczyciel śpiewu w latach 1783-1787; sopranista Franz Cecerelli, nauczyciel śpiewu chorałowego w latach 1783-1788; Leopold Mozart, nauczyciel fortepianu oraz skrzypiec w latach 1744-1786; ponadto koncertmistrzowie Ferdinand Seydl oraz Michael Haydn, a także Andrea Pinzger, pełniący funkcję koncertmistrza kapeli dworskiej ${ }^{7}$.

Na podstawie listów Leopolda Mozarta oraz jego córki Marii Anny wiadomo, że oprócz regularnej nauki w Kapellhaus Woelfl uczęszczał także na prywatne lekcje gry w domu rodziny Mozartów. Jego nauczycielem skrzypiec był Leopold Mozart, a Maria Anna, poufale zwana Nannerl, nauczała go prawdopodobnie gry na fortepianie. Jej właśnie zadedykował Woelfl swe powstałe parę lat później w Wiedniu Troi Sonates pour le Forte-piano seul op. $3^{8}$.

Częstą obecność młodego Woelfla w domu Mozartów potwierdzają zachowane listy Leopolda oraz zapiski z dziennika Marii Anny, w których to osoba Woelfla wspomniana była po raz pierwszy 29 lipca 1783 roku9 . Nannerl wskazuje w dzienniku, że młody Woelfl wraz ze swoim ojcem

$7 \quad$ R. Baum, dz. cyt., s. 9.

8 Treść dedykacji brzmi: „Gewidmet Mme. Anne de Sonnenburg, nèe Mozart”; cyt. za: M. Haider-Dechant, dz. cyt., s. 33.

9 Dziennik Marii Anny Mozart, wpis z 29-30.07.1783; za: Mozart. Briefe und Aufzeichnungen, Gesamtausgabe, red. W.A. Bauer, O.E. Deutsch, wyd. uzupełnione, Kassel 2005, t. 3, 1780-1786, s. 282 ( $\mathrm{nr} 761$ ). O ile nie wskazano inaczej, tłumaczenia pochodzą od autorki artykułu. 
Johannem Paulem udali się do Michalbeuren ${ }^{10}$. W listach Mozartów Woelfl określany jest jako „Seperl” bądź „Seperl Wölfl”. Określenie „Seperl" stanowi zdrobniałą formę imienia Joseph i można je przetłumaczyć jako Józio. W listach pojawia się także forma „der Verwalter Seperl”, która pochodzi ze złożenia imienia Woelfla ze stanowiskiem jego ojca ${ }^{11}$. Wiadomo także, że od grudnia 1783 roku do września 1785 roku młody pianista pobrał $\mathrm{w}$ domu tej rodziny ponad 236 lekcji muzyki. Świadczy o tym list Leopolda Mozarta, który w październiku 1785 roku pisał do córki:

\begin{abstract}
W nowym roku minęły dwa lata, odkąd jego ojciec [Johann Paul Wölfl] nic nie płacił, był u mnie osiem dni temu i według jego zapisków rachunek za wszystkie lekcje wyniósł 47 f 12 Xr. [...] To bzdury. [...] Widzisz wyraźnie, że wiele lekcji nie zostało zapisanych, poza tym chłopcem zajmowałem się zawsze po półtorej czy dwie godziny².
\end{abstract}

Ten nieco rozgoryczony ton Leopolda Mozarta wskazuje nie tylko, że lekcji było więcej, niż odnotował to ojciec Woelfla, ale również, że były one długie i intensywne.

Bez wątpienia w latach salzburskich Joseph Woelfl był bardzo częstym gościem rodziny Mozartów, nie tylko pobierał tam lekcje gry, ale także uczestniczył w rodzinnym muzykowaniu. Nadto w 1785 roku brał udział w wykonaniu opery Die Dorfdeputierten Johanna Lukasa Schubauera ${ }^{13}$ do tekstu Gottloba Ephraima Hermanna na podstawie

10 Dziś Michaelbeuern. Jest to niewielka miejscowość położona ok. $30 \mathrm{~km}$ na północ od Salzburga, znana przede wszystkim ze znajdującego się tam, pochodzącego z VIII wieku klasztoru benedyktyńskiego. Zob. http://www.salzburg.com/wiki/ index.php/Benediktinerabtei_Michaelbeuern [dostęp: 25.02.2016].

11 Od 1784 roku ojciec kompozytora pełnił stanowisko administratora w szpitalu św. Jana (Verwalter des St. Johannes-Spitals) w Mülln, ówczesnym przedmieściu Salzburga, zob. Mozart. Briefe..., dz. cyt., t. 6, Kommentar, s. 144.

12 „Aufs neue jahr sinds 2 Jahre, dass sein Vater nichts bezahlt hatte, und er war vor 8 Tag bey mir und nach sejner [sic] notierten Lecktionen Rechnung betrugs die ganze Zeit nur $47 \mathrm{f} 12 \mathrm{X}^{\mathrm{r}}$. [...] Das ist also Quark. [...] viele Lecktionen nicht aufgeschrieben worden, siehst du augenscheinlich, wo überdas den Buben alzeit anderhalb stunden, und 2 Stund [sic] meistens unter handen hatte". List Leopolda Mozarta do Nannerl z 27.10.1885; cyt. za: Mozart. Briefe..., dz. cyt., t. 3, s. 436 (nr 892).

13 Johann Lukas Schubauer (1749-1815) - niemiecki kompozytor oraz lekarz. Zasłynął przede wszystkim jako kompozytor singspieli. Opera Die Dorfdeputierten to jego najwybitniejsze dzieło, którego prapremiera odbyła się 3 maja 1783 roku 
komedii Il Feudatorio Carla Goldoniego ${ }^{14}$. W liście Leopolda Mozarta do Nannerl z grudnia 1786 roku czytamy: „Der Verwalter Sepperl [Joseph Woelfl] chciałby [...] dostać z powrotem swój egzemplarz Dorfdeputierten, gdyż gdy gra, nie potrafi ich już dobrze z pamięci odtworzyć"15. Mozartowie wspominają wielokrotnie również postać Johanna Paula Wölfla. Jak pisał Leopold, był on często chory i nie wróżono mu długiego życia ${ }^{16}$.

Zapiski Leopolda i Nannerl świadczą, że związki rodziny Wölflów z Mozartami były wręcz przyjacielskie. Joseph rozpoczął u nich naukę gry w wieku dziewięciu lat. Najpóźniejszy wpis z mozartowskiej korespondencji dotyczący młodego muzyka pochodzi z lutego $1787 \mathrm{roku}^{17}$.

28 maja 1787 zmarł Leopold Mozart, co oznaczało prawdopodobnie początek nowego etapu w życiu Josepha Woelfla. Można przypuszczać, że z powodu mutacji głosu musiał on także opuścić Kapellhaus. Przez trzy lata - od 1786 do 1788 roku - był też Woelfl uczniem benedyktyńskiego uniwersytetu w Salzburgu ${ }^{18}$. Brak natomiast informacji dotyczących jego osoby aż do 1790 roku, kiedy to siedemnastoletni wówczas muzyk opuścił po raz pierwszy mury Salzburga, by przez Wiedeń wyruszyć w prawie niekończącą się wędrówkę po Europie.

\section{Okres polski (1791-1795)}

Johann Paul Wölfl zdecydował się wysłać syna śladami Wolfganga Amadeusa Mozarta do Wiednia ${ }^{19}$. Wszystko wskazuje także na to, że Joseph Woelfl w 1791 roku udał się wraz z Mozartem do Pragi, gdzie dał koncert. Wspominano tam bowiem koncertującego tam młode-

w Monachium. Zob. H. Urlich, Schubauer, Johann Lukas, [w:] Die Musik in Geschichte und Gegenwart. Personenteil, red. L. Finscher, t. 15, Kassel 2006, s. 70-71.

14 Mozart. Briefe..., dz. cyt., t. 6, Kommentar, s. 233.

15 „Der Verwalter Sepperl möchte [...], das Dorfdeputierten Büchl zurück haben, weil er, wenn er spielt, nicht mehr recht auswendig kann”. Zob. list Leopolda Mozarta do Nannerl z 1.12.1786; cyt. za: Mozart. Briefe..., dz. cyt., t. 3, s. 616 (nr 1007).

16 List Leopolda Mozarta do Nannerl z 10.1784; cyt. za: Mozart. Briefe..., dz., cyt., t. 3, S. 350 (nr 826).

17 List Nannerl do Leopolda Mozarta z 02.1787; za: Mozart. Briefe..., dz. cyt., t. 4, 1787-1857, s. 32 ( $\mathrm{nr} 1028)$.

18 M. Haider-Dechant, dz. cyt., s. XXII.

19 R. Baum, dz. cyt., s. 12. 
go pianistę „W”. Sam Mozart miał wówczas powiedzieć: „Ten młody człowiek gra bardzo dobrze, ja jednak nie mam w tym udziału; być może nauczył się on czegoś od mojej siostry" ${ }^{20}$. Informacja ta wskazuje nie tylko na to, że osiemnastoletni Woelfl musiał już posiadać wysokie umiejętności gry; obala ona także pojawiający się często w literaturze przedmiotu mit, że - obok Leopolda - także Wolfgang Amadeus Mozart był nauczycielem Josepha.

Niestety nie wiemy dokładnie, jak wyglądały relacje między młodym muzykiem a mistrzem klasycyzmu. Prawdopodobne jest jednak, że to właśnie Wolfgang Amadeus polecił Woelfla polskiemu księciu Michałowi Kleofasowi Ogińskiemu ${ }^{21}$. W służbie Ogińskiego Woelfl spędził około piętnastu miesięcy w latach 1791-1792 22 . Informacja, że to właśnie Mozart polecił młodego muzyka Ogińskiemu, choć niepotwierdzona, powtarza się wielokrotnie w literaturze przedmiotu ${ }^{23}$. Książę Ogiński, urodzony w 1765 roku, był osiem lat starszy od swego nauczyciela. Okazał się utalentowanym kompozytorem oraz człowiekiem niezwykle wrażliwym i otwartym na muzykę, o czym świadczą jego Listy o muzyce, w których opisuje nie tylko swoje muzyczne zamiłowania i gusta, ale także liczne doświadczenia, związane z częstymi podróżami. Znał osobiście wielu muzyków-instrumentalistów, a także największych mistrzów kompozycji, m.in. Josepha Haydna, zaś w Wiedniu odbył nieznaną bliżej wizytę, w której udział wziął także Wolfgang Amadeus Mozart ,jakieś trzy lata przed jego śmiercią" (tj. zapewne w $1788 \mathrm{roku}{ }^{24}$. Ogiński dodał, że nie miał przyjemności przeprowadzić rozmowy ze słynnym muzykiem, gdyż ten opuścił salon wcześniej. Na podstawie wspomnień księcia, wskazujących na

20 „Der junge Mann spielt recht brav, aber ich habe keinen Antheil daran; vielleicht hat er etwa von meiner Schwester profitiert". Zob. G.N. Nissen, Biographie W.A. Mozarts, Leipzig 1828; cyt. za: M. Haider-Dechant, dz. cyt., s. XXII.

Olga Baird przypuszcza, że podobna rekomendacja mogła zostać raczej przekazana wujowi Michała Kleofasa - księciu Michałowi Kazimierzowi Ogińskiemu. Zob. O. Baird, Joseph Woelfl in Warsaw: His Polish Patrons, Pupils, Addressees and Friends, [w:] „The Musical Times” 159 (2018), nr 1942, s. 68-70. Por. M.K. Ogiński, Listy o muzyce, oprac. T. Strumiłło, Kraków 1956, s. 97. Woelfl Joseph, [w:] Biographisch-Bibliographisches Quellen-Lexikon der Musiker und musikgelehrten, red. R. Eitner, t. 10, Leipzig 1904, szp. 286-288; zob. także: A. Chybiński, Woelffl Joseph, [w:] Słownik muzyków dawnej Polski do roku 18oo, Kraków 1949, s. 138; H. Feicht, Musikalische Beziehungen zwischen Wien und Warschau zur Zeit der Wiener Klassiker, „Studien zur Musikwissenschaft” 25 (1962), s. 178.

24 M.K. Ogiński, dz. cyt., s. 124-125. 
jego rozległe kontakty z ówczesną elitą świata muzyki, można wysnuć hipotezę, że mógł on poznać kogoś z otoczenia Mozarta, kto pośredniczyłby we wspominanej często rekomendacji. Nie można także wykluczyć, że książę podczas swoich licznych podróży w jednym z salonów Wiednia poznał samego Josepha Woelfla i zaproponował mu tę posadę bezpośrednio.

W historii Michał Kleofas Ogiński zapisał się przede wszystkim jako mistrz poloneza. Alina Żórawska-Witkowska zwraca uwagę na fakt, iż właśnie w czasie współpracy z Woelflem powstały pierwsze kompozycje Ogińskiego należące do tego gatunku ${ }^{25}$. Także Woelfl w czasie pobytu w Polsce napisał poloneza, stanowiącego część jego sonaty (w katalogu sporządzonym przez Margit Haider-Dechant oznaczonej jako Frühwerk 7 [Fw 7] $)^{26}$, wykonanej podczas koncertu publicznego w Warszawie w 1792 roku $^{27}$. Ogiński wiele lat później wspominał swojego pedagoga nader pochlebnie:

\footnotetext{
Woelfl był w mojej służbie w ciągu jakiś 15 miesięcy w Warszawie, w latach 1791 i 1792. Później dał się poznać bardzo korzystnie w Paryżu, Londynie i wielu innych stolicach jako kompozytor i wykonawca swych utworów, które przedstawiały wiele trudności dla pianistów nieposiadających tak długich jak on palców; był on w stanie wykonywać z największą łatwością gamy z rulandami oraz akordy decymowe ${ }^{28}$.
}

Ogiński, pisząc te słowa wiele lat po zakończeniu współpracy z Woelflem, nie tylko wspominał muzyka z wielkim sentymentem, znał także jego późniejsze sukcesy jako kompozytora oraz wirtuoza fortepianu w Europie.

25 A. Żórawska-Witkowska, The Musical Life in Warsaw at Wölfl's Time (1791-1795), „Joseph Woelfl-Almanach” 2012/13, red. M. Haider-Dechant, H. Dechant, s. 95.

26 Margit Haider-Dechant w katalogu dzieł kompozytora Joseph Woelfl. Verzeichnis seiner Werke stosuje następujące oznaczenia jego utworów: dzieła opusowane op., dzieła wczesne - Fw, dzieła bez opusu - WoO.

27 L. Bernacki, Teatr, dramat i muzyka za Stanisława Augusta, t. 1, Źródła i materiały, Warszawa 1979, s. 367-368.

28 M.K. Ogiński, dz. cyt., s. 97. 


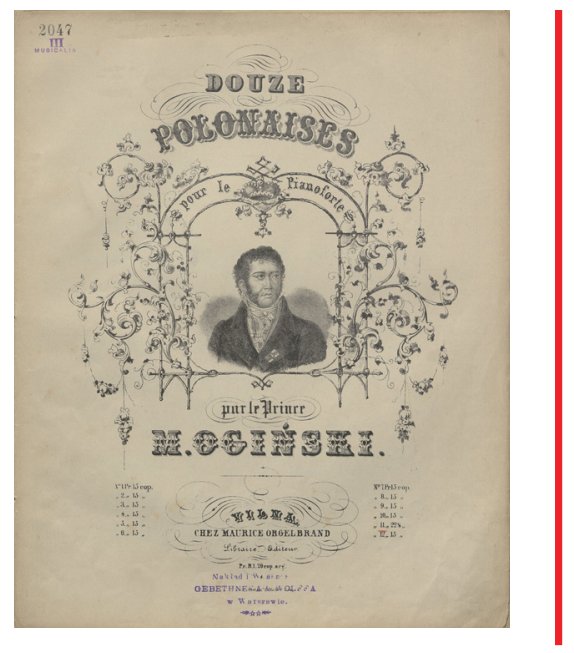

Ilustracja 2. Michał Kleofas Ogiński, Douze polonaises pour le pianoforte, Wilno, Księgarnia i Skład Nut Maurycego Orgelbranda, ok. 1864 r. Kopia: BN, sygn. Muz. 2047 III.

W 1792 roku Woelfl opuścił dwór Ogińskich i osiadł w Warszawie, gdzie działał jako nauczyciel gry na fortepianie, prawdopodobnie już niezależny od księcia. Nie wiadomo, kiedy Woelfl wyjechał z Warszawy. Istnieje prawdopodobieństwo, że przebywał tam przez kolejne trzy lata, aż do trzeciego rozbioru Polski w 1795 roku. Bardzo szybko zyskał w mieście sławę, stał się bowiem wziętym i dobrze opłacanym pedagogiem, nauczającym młodzież magnacką oraz dzieci wysoko usytuowanych rodzin ${ }^{29}$. Heinz Wolfgang Haman podaje, że był on m.in. nauczycielem muzyki syna warszawskiego bankiera, Piotra Teppera von Fergusona ${ }^{30}$. Nie wiadomo jednak dokładnie, które spośród licznych dzieci Fergusona nauczał Woelfl. Informacja o powiązaniu kompozytora z tą bogatą warszawską rodziną wskazuje, że jego pozycja w Warszawie musiała być wysoka.

Obok aktywności pedagogicznej Woelfl prowadził w polskiej stolicy także działalność koncertową. Afisz z 11 września 1792 roku donosi, że Joseph Woelfl, „metr klawikorda, który zmyśla jeszcze dawać lekcye

29 A. Żórawska-Witkowska, Muzyka na dworze i w teatrze Stanisława Augusta, Warszawa 1995, s. 100.

30 H.W. Hamann, Wölfl Joseph, [w:] The New Grove Dictionary of Music and Musicians, red. S. Sadie, t. 20, London 1980, s. 508. 
w tej stolicy", wystąpił na koncercie wybitnego wiedeńskiego klarnecisty Antona Standlera, przyjaciela Wolfganga Amadeusa Mozarta. Podczas koncertu Woelfl wykonał na fortepianie bliżej nieokreślony koncert $^{31}$. Niewiele ponad miesiąc od pierwszego publicznego występu Woelfl ponownie prezentował się warszawskiej publiczności. Tym razem jednak to on stał się głównym bohaterem koncertu. Afisz zapowiadający to wydarzenie podawał:

\begin{abstract}
26. [października] Piątek. Koncert p. Woelfla, kompozytora i metra klawikordu. 1. Symfonia, kompozycyi Hayden 2. P. Woelf odegra koncert na fortepianie swojej kompozycyi. 3. P. Endler ${ }^{32}$ odegra sonatę na harmonice. 4. P. Woelfl odegra sonatę z nową polonezą, własnej kompozycyi. 5. Symfonia. 6. P. Endler odegra rondo. 7. P. Woelfl odegra na fortepianie kozaka bardzo sławnego, z 10 waryacyami, swojej kompozycyi. 8. Symfonia, kompozycyi Pleyela33. Fortepian zrobiony wcale nowo przez Schweinfleischa ${ }^{34}$. Wstęp 6 zł. Bilety u P. Woelfl (Marywil 8, II.p). Początek o godz. 6-tej35.
\end{abstract}

Margit Haider-Dechant stwierdza, że w obydwu przypadkach chodzi prawdopodobnie o ten sam, dziś zaginiony koncert fortepianowy i w katalogu dzieł Woelfla nadaje mu numer Fw 9. Nie zachowały się także inne wymienione na afiszu kompozycje Woelfla, tj. sonata z polonezem, skomponowana przypuszczalnie w czasie służby na dworze Ogińskich ( $\mathrm{Fw} 7$ ) oraz kozak z dziesięcioma wariacjami, po którym również nie pozostały do naszych czasów żadne ślady (Fw 8).

Z 1793 roku pochodzi kolejny ślad dotyczący muzycznej działalności Josepha Woelfla. Tym razem muzyk pojawił się w Grodnie, gdzie jesienią wystąpił w teatrze publicznym. Wyjazd Woelfla z Warszawy

31 Cyt. za: L. Bernacki, dz. cyt., s. 364.

32 Wilhelm Gottfried Endler, koncertował w teatrze stołecznym na harmonice; A. Żórawska-Witkowska, dz. cyt., s. 94. Ignaz Joseph Pleyel (1757-1831) - austriacki kompozytor oraz budowniczy fortepianów. Zob. M. Cranmer, Pleyel, Ignace Joseph, [w:] The New Grove Dictionary of Music and Musicians, red. S. Sadie, t. 19, London 2001, s. 918-922.

34 Friedrich Schweinfleisch - nadworny organmistrz Stanisława Augusta odpowiedzialny za naprawę oraz strojenie fortepianów na dworze, także budowniczy fortepianów. Instrument, na którym koncertował Joseph Woelfl, został prawdopodobnie zakupiony w 1792 roku dla dworu Stanisława Augusta, być może jednak Schweinfleisch wypożyczył jeden ze swoich instrumentów w celach reklamowych. Zob. A. Żórawska-Witkowska, dz. cyt., s. 278.

Afisz po polsku i francusku. Cyt. za: L. Bernacki, dz. cyt., s. 367-368. 
był zapewne związany z obradami ostatniego sejmu Rzeczpospolitej szlacheckiej, które miały miejsce w Grodnie od 17 czerwca do 23 listopada 1793 roku. Do zwołania sejmu nad Niemnem nakłonił króla Stanisława Augusta nowy ambasador Rosji - Jakob Johann Sievers. Świadom konsekwencji, król zgodził się na warunki Rosji i 22 lipca 1793 roku delegacja sejmowa w Grodnie złożyła podpis pod kolejnym traktatem rozbiorowym ${ }^{36}$.

W Teatrze Grodzieńskim, którego działalność kontrolował marszałek wielki koronny Michał Jerzy Wandalin Mniszech (Mniszek) ${ }^{37}$, obok sztuk scenicznych organizowano także koncerty instrumentalne i wokalne. 9 listopada 1793 roku z prośbą o zgodę na koncert publiczny wystąpił Joseph Woelf ${ }^{38}$. Prośba została sformułowana w języku polskim, nie napisał jej więc zapewne sam kompozytor. Podpisał ją jednak własnoręcznie. Czytamy w niej:

Jaśnie Wielmożny Panie Dobrodzieju. Woiażuiąc po różnych kraiach za-
bawiałem publiczność wydawaniem koncertów instrumentalnych. Z tych
tedy okoliczności do Grodna zbliżyłem się abym podobnież przez czas jaki
mógł Publiczność zabawić. Przeto [słowo nieczytelne] względów Jego
Pana Dobrodzieja aby mi dane było pozwolenie od Jurysdykcji Jego Pana
wydawania koncertów na Teatrze Grodzieńskim. Jego Pana Dobrodzieja
Najniższy Sługa. Joseph Woelfl.

Woelfl otrzymał odpowiedź pozytywną, a dokument podpisał i zgodę na koncert wydał 9 listopada 1793 roku niejaki J. Sobolewski - sędzia marszałkowski.

Zachowana w Litewskim Państwowym Archiwum Historycznym w Wilnie prośba jest równocześnie pierwszym znanym nam dokumentem podpisanym przez kompozytora, gdzie używa on zmienionej pisowni swojego nazwiska „Woelfl”, zamiast wcześniejszego „Wölfl”.

Nie wiadomo, kiedy muzyk ostatecznie opuścił Rzeczpospolitą. Kolejny ślad dotyczący działalności Woelfla pojawia się w 1795 roku i potwierdza jego powrót do Wiednia. Kompozytor przywiózł spory majątek zgromadzony przez lata pobytu w Polsce. Wszystko wskazuje

36 Z. Jędrychowski, Teatra grodzieńskie 1784-1864, Warszawa 2012, s. 46-47.

37 Tamże, s. 48.

38 Kniga raznych zajawlenij i raportow $w$ Marszałkowskom sudie, 1793, Litewskie Państwowe Archiwum Historyczne w Wilnie, sygn. D.A. 4204, k. 424. 
na to, że Woelflowi wiodło się tu całkiem dobrze, a przyczyną jego decyzji o opuszczeniu kraju musiały być rozbiory Rzeczpospolitej i związane z tym niepokoje.

\section{Wiedeń (1795-1799)}

Po powrocie z Rzeczpospolitej Joseph Woelfl niezwykle szybko wkroczył w życie europejskiej stolicy muzyki - Wiednia. Już 21 października 1795 roku w Theater auf der Wieden odbyła się premiera jego pierwszej opery, singspielu Der Höllenberg (w katalogu autorstwa Margit Haider-Dechant oznaczony jako WoO 2), skomponowanej do libretta Emanuela Schikanedera. Der Höllenberg, oder Prüfung und Lohn to opera heroikomiczna w dwóch aktach, składająca się z uwertury i dwudziestu dziewięciu numerów ${ }^{39}$. Jak podaje w swoim dzienniku Ignaz Ritter von Seyfried, poza prapremierą dzieło to wystawiono w Wiedniu jeszcze dziewiętnaście razy, po raz ostatni 8 marca 1799 roku $^{40}$.

Niedługo po premierze pierwszego dzieła scenicznego Woelfla, tym razem $\mathrm{w}$ wiedeńskim Hoftheater, odbyło się wystawienie kolejnej jego opery - Das Schöne Milchmädchen, oder Der Guckkasten ( $\mathrm{WoO}_{3}$ ), skomponowanej do tekstu Josepha Richtera. Ten jednoaktowy singspiel składa się z uwertury i czternastu numerów muzycznych ${ }^{41}$. Rok później, 3 grudnia 1797 roku, w Theater auf der Wieden wystawiono trzeci już singspiel kompozytora, Der Kopf ohne Mann (WoO 6). Libretto tej dwuaktowej opery heroikomicznej stworzył Joachim Perinet, a jej akcja toczy się u bram Wiednia w $1529 \mathrm{roku}^{42}$. Jeszcze tego samego roku, 26 marca, muzyka Woelfla ponownie rozbrzmiała na deskach Theater auf der Wieden. Tym razem prezentowano tam dwuaktowy singspiel-pasticcio Liebe macht $k u$ rzen Prozess, oder Heirath aufgewisse Art (WoO 12), ponownie do libretta Joachima Perineta. Obok Josepha Woelfla, który stworzył większą część partytury, wymienić należy także nazwiska Johanna Henneberga, Matthiasa Stegmeiera, Franza Antona Hoffmeistera, Jakoba Haibela, Josepha Triebenseego, Franza Xavera Süßmayra oraz Ignaza Rittera von Seyfrieda.

39 M. Haider-Dechant, dz. cyt., s. 184.

40 S. Puderlitschek, Das Freyhaus-Theater auf der Wieden. Das Tagebuch von Ignaz Ritter von Seyfried 1795 bis 12. 1801, praca magisterska, Universität Wien, Wien 1997; cyt. za: M. Haider-Dechant, dz. cyt., s. 189.

41 M. Haider-Dechant, dz. cyt., s. 196.

42 Tamże, s. 207. 
Wiedeńska kariera młodego kompozytora rozwijała się nadzwyczaj pomyślnie, zyskiwał zatem pochlebne opinie ówczesnej prasy. Jako przykład przytoczyć można krótką wzmiankę z 24 marca 1799 roku, która pojawiła się na łamach „Allgemeine Musikalische Zeitung”:

Spośród nowych oper, które zostały tutaj [w Wiedniu] nagrodzone szczególnym aplauzem i wyróżniają się spośród innych dzieł, wymienić można Das Sotteraneo czy Das Burgverlies [Ferdinanda] Pära, Falstaff o sia Le tre burle [Antonia] Salierego oraz Kopf ohne Mann Wölfla ${ }^{43}$.

W związku z obecnością Woelfla na wiedeńskich scenach oraz w tamtejszych salonach koncertowych nazwisko kompozytora coraz częściej pojawiało się także w niemieckojęzycznej prasie muzycznej. Regularnie zaczęto publikować pochlebne recenzje jego dzieł w „Allgemeine Musikalische Zeitung", która od listopada 1798 roku nieraz donosiła też o najnowszych osiągnięciach muzyka oraz podawała informacje dotyczące jego nowości wydawniczych, i to jeszcze w kilka lat po śmierci Woelfla. Kompozytor był tam oceniany nie tylko jako twórca dzieł scenicznych. Coraz częściej bowiem występował w Wiedniu jako wirtuoz fortepianu.

Wśród wielu muzycznych oraz kompozytorskich osiągnięć Josepha Woelfla żadne nie przyniosło mu tak wielkiej sławy i chwały jak niezapomniany artystyczny pojedynek z Ludwigiem van Beethovenem. To właśnie owa rywalizacja oraz próby porównywania umiejętności dwóch wirtuozów fortepianu doprowadziły do podziału wiedeńskiego społeczeństwa. Muzyków konfrontowano ze sobą już przed ich oficjalnym spotkaniem, a mieszkańcy Wiednia zaczęli dzielić się na zwolenników jednego bądź drugiego. Wśród zainteresowanych nie zabrakło znanych postaci, jak choćby hrabia Karl von Lichnovsky, który opowiedział się po stronie Beethovena, czy baron Raimund Wetzlar von Plankenstern, przychylny Woelflowi. To właśnie w willi Plankensterna, w okolicach cesarskiego pałacu Schönbrunn, wiosną 1798 roku doszło do starcia dwóch muzyków.

Ignaz von Seyfried, naoczny świadek wydarzenia, zauważył, że Ludwig van Beethoven, znany w Wiedniu już od pewnego czasu,

43 „Von den neuen Opera, welche hier mit Beyfall gegeben worden sind, und worunter sich besonders das Sotteraneo oder das Burgverlies von Pär, Falstaff o sia Le tre burle von Salieri, und der Kopf ohne Mann von Wölfl”. Zob. „Allgemeine Musikalische Zeitung", 24.03.1799, s. 448. 
postrzegany był jako pianista pierwszej rangi i przez długi czas nie miał w mieście godnego siebie przeciwnika. Powstały poprzez ciągłe porównywanie obu muzyków konflikt spowodował, według Seyfrieda, swoisty podział melomanów, przypominający dawny paryski spór gluckistów i piccinistów. Richard Baum przytacza wspomnianą relację Seyfrieda:

Każdy z pianistów prezentował swoje najświeższe duchowe osiągnięcia; dawał się ponieść, pierwszy bądź drugi, chwilowym natchnieniom swojej rozpalonej fantazji, niepohamowanemu biegowi; obydwaj zasiedli do dwóch fortepianów i improwizowali naprzemiennie na zadawane sobie tematy oraz stworzyli Capriccio na cztery ręce, które gdyby w momencie narodzenia zostało uwiecznione na papierze, z pewnością stawiłoby czoło nietrwałości. W kwestii technicznej trudno było przyznać palmę pierwszeństwa jednemu z nich. Woelfl był przez dobrotliwą naturę tak szczodrze olbrzymimi dłońmi obdarzony, iż decymy obejmował z taką łatwością, jakiej inni do oktawy potrzebowali, co umożliwiało mu ciągi dwudźwiękowych pasaży w zadanych interwałach wykonywać w tempie błyskawicy. [...] Woelfl, wychowany w mozartowskiej szkole, pozostawał zawsze taki sam; nigdy płytki, ale klarowny i właśnie dlatego bardziej dostępny; sztuka służyła mu jako środek do osiągnięcia celu, w żadnym wypadku jako ozdoba i atrapa suchej uczoności ${ }^{44}$.

Opis ten zawiera liczne pochwały pod adresem Woelfla, wynik pojedynku rozstrzygnięto bowiem na jego korzyść. Wiadomo jednak, że także Beethoven cenił wysoko młodego rywala. Z kolei Woelfl uważał

44 „Jeder trug seine jüngste Geistesproducte vor; bald ließ der Eine oder der Andere den momentanen Eingebungen seiner glühenden Phantasie freyen, ungezügelte Lauf; Bald setzten sich Beide an zwei Pianoforte, improvisierten wechselweise über gegenseitig sich angegebene Themas und schufen also gar manches vierhändige Capriccio, welches hätte es im Augenblicke der Geburt zu Papier gebracht werden können. An mechanischer Geschicklichkeit dürfte es schwer, vielleicht unmöglich gewesen sein, einem der Kämpfer vorzugsweise die Siegespalme zu verleihen; ja, Wölfl war von der gütigen Natur noch mütterlicher bedacht indem sie ihn mit einer Riesenhand ausstattete, die ebenso leicht Dezimen, als andere Menschenkinder Oktaven spannten und es ihm möglich machte, fortlaufende, doppelgriffige Passagen in den genannten Intervallen mit Blitzesschnelligkeit auszuführen. [...] Wölfl hingegen, in Mozarts Schule gebildet immerdar sich gleich; nie flach, aber stets klar, und eben deswegen der Mehrzeit zugänglicher; Kunst diente ihm bloß als Mittel zum Zwecke, in keinem Falle als Prunk- und Schaustück trockenen Gelehrttuens". Cyt. za: R. Baum, dz. cyt. s. 15. 
Beethovena za mistrza i dedykował mu swoje trzy sonaty na fortepian op. 6 (1799). Dwa lata później na wieść o rzekomej śmierci wielkiego mistrza napisał do swego wydawcy: „Czy Beethoven zmarł, musi dać Pan jeszcze bliższe informacje, ja żałowałbym tego ogromnie, ponieważ byliśmy tak amici, jak i rivali"45.

Na większy obiektywizm silił się, prezentując sylwetki Beethovena oraz Woelfla, autor opublikowanego na łamach „Allgemeine Musikalische Zeitung" sprawozdania z 22 kwietnia 1799 roku, przedstawiającego postaci wiedeńskich wirtuozów fortepianu. Wśród najbardziej znanych instrumentalistek autor wymienił dwie pianistki oraz kompozytorki - Josephę Barbarę Auernhammer oraz Magdalenę von Kurzbeck. Spośród męskich wirtuozów fortepianu w raporcie wyróżnił Ludwiga van Beethovena oraz Josepha Woelfla, których umiejętności podzieliły wiedeńskie środowisko:

Zdania dotyczące pierwszeństwa jednego lub drugiego są tutaj podzielone: zdaje się jednak, jakby więcej zwolenników znajdowało się po stronie ostatniego z nich [Woelfla]. Postaram się jednak coś o każdym z nich przedstawić tak, by nie dać pierwszeństwa żadnej ze stron. Gra Beethovena jest niezwykle błyskotliwa, niezbyt jednak delikatna, przez co jest niekiedy niezrozumiała. Pokazuje się on najkorzystniej w swobodnej improwizacji. Niezwykle zadziwiające jest, z jaką łatwością i jednocześnie zdecydowaniem następują kolejne pomysły na każdy z zadawanych mu tematów, nie przeprowadza on tylko prostej wariacji [...], ale naprawdę koncertuje. [...] Pierwszeństwo Woelfla polega jednak na tym, iż przy gruntownej muzycznej uczoności i prawdziwej godności w kompozycji, frazie, która zdaje się być niemożliwa do wykonania, wykazuje on lekkość, precyzję i zrozumiałość, które zadziwiają; [...] stąd wszystkie jego wykonania są zaplanowane i wyjątkowe, równie ujmujący i przyjemny jest on w Adagio, odległym tak od pustki, jak i nadmiaru, że nie należy się zadziwiać, a tylko czerpać przyjemność 46 .

45 „Ob Beethoven tot ist, müssen Sie noch nähere Nachrichten geben, ich würde es außerordentlich bedauern, wenn wir gleich amici rivali gewesen sind". Zob. W. Hitzig, Die Brife Joseph Wölfls an Bretikopf u. Härtel, [w:] Jahrbuch von Breitkopf u. Härtel auf das Jahr 1926, Leipzig 1926, s. 58-59; cyt. za: Beethoven aus der Sicht seiner Zeitgenossen in Tagebüchern, Briefen, Gedichten und Erinnerungen, red. K.M. Kopitz, R. Ladenbach, t. 1, München 2009, s. 1104-1105.

46 „Die Meynungen, über den Vorzug des Einen vor dem Anderen, sind hier getheilt: doch scheit es, als ob die größere Parthey auf die Seite des letztern neigte. Ich 
Joseph Woelfl, wywodzący się z mozartowskiej szkoły, bywał porównywany do Wolfganga Amadeusa Mozarta i przedstawiany jako nowy ulubieniec wiedeńskiego społeczeństwa. Woelfl przypominał Mozarta niestety także poprzez jego zamiłowanie do gier, znany był jako nałogowy bilardzista ${ }^{47}$. Mimo to jeszcze wiele lat później oceniano go jako jednego z najwybitniejszych muzyków Wiednia. Carl Czerny w 1842 roku pisał, że Woelfl to jeden z najlepszych pianistów, podkreślał wspaniałość jego brawurowej gry i stawiał go w jednym rzędzie z czeskimi kompozytorami i pianistami: Josephem Gelinkiem (Jelinkiem) czy Josephem Lipavskim ${ }^{48}$.

W latach wiedeńskiej działalności Josepha Woelfla powstały liczne kompozycje: sonaty fortepianowe op. 1, 3, 6, 7a; sonaty na fortepian i skrzypce op. 2, 7b; kwartet smyczkowy op. 4; trio fortepianowe op. 5 dedykowane Josephowi Haydnowi; tańce oraz wariacje.

Richard Baum podaje, że muzyk otoczony był mecenatem barona Raimunda Wetzlara von Plankensterna. Woelfl miał go poznać za pośrednictwem Konstancji i Wolfganga Amadeusa Mozartów, jeszcze podczas swojego pierwszego pobytu w Wiedniu. Informacja ta zdaje się prawdopodobna, gdyż Mozartowie mieli bliskie relacje z tym bogatym wiedeńskim bankierem ${ }^{49}$. Z listu rekomendacyjnego wdowy po Mozarcie wiadomo zaś, że miała ona o Josephie Woelflu jak najlepsze zdanie,

will mich bemühen, Ihnen das Eigene Beyder anzugeben, ohne an jenem Vorrangsstreite Theil zu nehmen. Beethovens Spiel ist äußerst brillant, doch weniger delikat, und schlägt zuweilen in das Undeutliche über. Er zeigt sich am allervorthelhafsten in der freyen Phantasie. Und hier ist es wirklich ganz außerordentlich, mit welcher Leichtigkeit und zugleich Festigkeit in der Ideenfolge B. auf der Stelle jedes ihm gegebene Thema, nicht etwa nur in den Figuren variirt $[. .$.$] sondern$ wirklich ausführt. [...] Aber Vorzüge von ihm hat Wölfl darin, daß er, bey gründlicher musikalischer Gelehrsamkeit und wahrer Würde in der Komposition, Sätze, welche geradehin unmöglich zu exekutieren scheinen, mit einer Leichtigkeit, Präcision und Deutlichkeit vorträgt, die in Erstaunen versetzt; [...] und daß sein Vortrag überall so zweckmäßig und besonders auch ihm Adagio so gefällig und einschmeichelnd, gleichfern von Kahlheit und Ueberfüllung ist, daß man nicht blos bewundern, sondern auch genißen kann”. Zob. „Allgemeine Musikalische Zeitung", 15.05.1799, s. 524-525.

47 R. Baum, dz. cyt., s. 14.

48 Beethoven aus der Sicht..., dz. cyt., s. 200.

49 W latach 1782-1783 Wolfgang Amadeus oraz Konstancja mieszkali nieodpłatnie w wiedeńskiej rezydencji barona na Hohe Brücke, został on także ojcem chrzestnym ich syna Raimunda, którego nazwano tak na cześć barona. Zob. S.P. Keefe, Wetzlar von Plankenstern, [w:] The Cambridge Mozart Encyclopedia, red. tenże, C. Eisen, Cambridge 2006, s. 531. 
na co mogły mieć wpływ jej wcześniejsze wspomnienia dotyczące relacji między muzykiem a jej zmarłym mężem. W lutym 1799 roku w liście do wydawnictwa Breitkopf \& Härtel Konstancja pisała:

\begin{abstract}
Wielce Szanowni Panowie, pozwalam sobie polecić Panom serdecznie dostawcę tego listu, mojego przyjaciela Pana Woelffla [sic], zręcznego muzyka i kompozytora. Wszystkie uprzejmości, jakie będzie on Panom zawdzięczał, odbierać będę jako mnie osobiście uczynione, ja zaś będę mieć zaszczyt obdarzyć panów najwyższym szacunkiem, Szanowni Panowie, oddana służebnica, Constance Mozart ${ }^{50}$.
\end{abstract}

Słowa te dowodzą, że Josepha Woelfla oraz Mozartów musiały łączyć także w Wiedniu bliskie relacje.

Pełen wrażeń okres wiedeński nie ograniczał się tylko do sukcesów zawodowych. W sierpniu 1798 roku kompozytor poślubił aktorkę Theresę Klemm, która rok później obdarzyła muzyka pierwszym potomkiem. 28 sierpnia 1799 roku szczęśliwy ojciec pisał w liście z podróży do swojego wydawcy, że niedawno przyszedł na świat jego syn, który już podczas narodzin poruszał rytmicznie prawą ręką ${ }^{51}$.

Niespokojna dusza kompozytora nie pozwoliła mu zbyt długo pozostać w Wiedniu u boku nowo założonej rodziny. W marcu 1799 roku wyjechał do Pragi, co zapoczątkowało okres europejskich podróży.

\title{
Czas podróży (1799-1801)
}

Swój trwający dwa lata okres podróży rozpoczął Joseph Woelfl od Pragi, gdzie koncertował po raz pierwszy 17 marca 1799 roku. Korespondent "Allgemeine Musikalische Zeitung” donosił o wielkim powodzeniu kompozytora, zaznaczając, że sale koncertowe podczas jego występów

50 „Höchstgeehrte Herrn, ich nehme mir die freyheit Ihnen den Ueberbringer dieses Herrn Woelffl, einen geschikten Musikus und Componisten, als meinen freund, auf das beßte zu empfehlen. Die Gefälligkeiten, die er Ihnen zu danken haben wird, werde ich als mir erzeugt ansehen, und sie werden die Hochachtung vernehmen, mit welcher ich die Ehre habe zu seyn, höchstgeehrte Herrn, Ihre ergebenste dienerin Constance Mozart". Zob. list Konstancji Mozart do wydawnictwa Breitkopf \& Härtel z 13.02.1799; cyt. za: Mozart. Briefe..., dz. cyt., t. 4, s. 227 (nr 1235).

51 W. Hitzig, dz. cyt., s. 50. 
wypełnione były po brzegi ${ }^{52}$. Opinię tę potwierdził także obecny na koncercie czeski kompozytor i nauczyciel muzyki Wenzel Johann Tomaschek, który w swojej Selbstbiographie wspominał: „Woelfl zagrał niezwykle czysto i precyzyjnie koncert swojego autorstwa z taką lekkością rąk, jakiej nikt inny nie mógłby osiągnąć" ${ }^{53}$. Podczas praskiego koncertu Woelfl mógł wykonać swój koncert, który powstał w latach warszawskich - dziś uznany za zaginiony, w katalogu jego dzieł oznaczony jako Fw 9 - a także Fantazje f-moll KV 608 Wolfganga Amadeusa Mozarta ${ }^{54}$. Wspomnienia świadka, choć bardzo pochlebne, zawierają także elementy krytyki. Tomaschek zarzucił bowiem Woelflowi, że jego gra nie trafiała do wnętrza słuchacza, lecz starała się go zadziwiać.

Kolejne ślady dotyczące działalności austriackiego kompozytora pojawiają się w Lipsku, gdzie - zgodnie z informacją zamieszczoną w „Allgemeine Musikalische Zeitung” - Woelfl dał dwa koncerty w kwietniu 1799 roku $^{55}$. Pierwszy z nich odbył się 11 kwietnia w sali koncertowej Gewandhaus, zaś drugi, uzupełniający występ miał miejsce w tym samym wnętrzu 23 kwietnia. $Z$ tej okazji redakcja pisma zamieściła obszerną relację:

Pan Wölfl z Wiednia, którego na łamach tego pisma wielokrotnie wspominali już różni autorzy, z okazji targów św. Michała dał tutaj w Lipsku dwa koncerty, które się spośród występów innych podróżujących wirtuozów pozytywnie wyróżniły, tak jak Pan W. sam wyróżnia się wśród innych wirtuozów. Dlatego za nasz obowiązek uważamy opublikowanie szczególnego oświadczenia i publiczne podziękowanie za darowaną nam przyjemność. [...] Na podstawie zaprezentowanego nam utworu, który pochodził z jego najnowszej opery: Der Kopf ohne Mann - stwierdzić można, iż dzieło to należy z pewnością do najwspanialszych kompozycji ostatniego czasu i zasługuje na pochwały, które otrzymało w Wiedniu oraz Pradze. Dwoma krótkimi fragmentami dzielimy się w załączniku numer XIII56. W jego kon-

52 "Allgemeine Musikalische Zeitung”, 10.04.1799, s. 444.

53 „Woelfl spielte von seiner Komposition ein Konzert mit beispielloser Reinheit und Präzision, wie es bei so ungeheurer Spannung seiner Hände wohl niemand anderer herausbringen dürfte". Zob. W. Tomaschek, Selbstbiographie, Prag 1845; cyt. za: M. Haider-Dechant, dz. cyt., s. LIII.

54 Tamże.

55 „Allgemeine Musikalische Zeitung”, 29.05.1799, s. 550.

56 Załącznik XIII do tego numeru „Allgemeine Musikalische Zeitung” zawierał arię Kiliana na głos i klawesyn z pierwszej części opery oraz marsz Fort, fort zu Pferde 
cercie panuje, obok pięknej oryginalności, niezwykle rzadkie połączenie siły i kruchości. Z okazji swojej wizyty skomponował on kantatę na głos solowy z towarzyszeniem fortepianu do wiersza Die Geister des See's z tegorocznego Schillerowskiego Musenalmanach; spośród jego dzieł poznaliśmy także nową sonatę na fortepian i flet, kwartety itd., które należą do najwyśmienitszych kompozycji w zakresie tych gatunków. Poprzez nasze uwagi, które nie wyrażają tylko naszej opinii, ale są głosem całej publiczności, chcielibyśmy wzbudzić zainteresowanie postacią Pana Wölfla, który udaje się stąd do Drezna, Berlina i Hamburga, aby poświęcono mu tam tyle uwagi, na ile zasługuje! Redakcja57.

Ten rozbudowany cytat stanowi niezwykle cenny przekaz opinii dotyczących ówczesnej działalności Woelfla. Redakcja „Allgemeine Musikalische Zeitung” nie tylko przedstawiała muzyka jako wirtuoza fortepianu, zwracała uwagę także na jego działalność kompozytorską, niezwykle pochlebnie ją oceniając. Wspomniana w recenzji sonata

fort na chór i klawesyn. Zob. „Allgemeine Musikalische Zeitung”, dz. cyt., Beilage XIII (XXXXI).

57 „Herr Wölfl aus Wien, dessen schon mehrmals von ganz verschiedenen Männern in diesen Blättern rühmlich Erwähnung gethan worden ist, gab bey Gelegenheit der Michaelismesse zwey Konzerte hier in Leipzig, die sich vor so manchen andern Konzerten reisender Virtuosen eben so vortheilhaft auszeichneten, als sich Herr W. selbst von vielen andern Virtuosen auszeichnet und die deshalb eine besondere Anzeige ans zur Pflicht, und einen öffentlichen Dank uns zum Vergnügen machen. Bekanntlich ist er Komponist für Theater- und Kammermusik, und zugleich Virtuos auf dem Pianoforte. Alle Kompositionen, die wir hier von ihm zu hören bekamen, zeugen von eben so viel Genie, als Kenntnis; sein bewundernswerthes Spiel ist bekannt. Nach den Stücken, welche er uns aus seiner neuesten Oper: Der Kopf ohne Mann - gab, zu urtheilen, gehört diese Arbeit gewiss zu den auszeichneten musikalischen Kunstprodukten der letzten Jahre, und verdient den Beyfall, welchen sie in Wien und Prag gefunden, vollkommen. Wir theilen zwey kleine Sätze daraus als Beylage No. XIII. mit. In der Komposition seiner Konzerte herrscht, bey schöner Originalität, eine so äußerst seltene Verbindung von Kraft und Zartheit. Bey seinem Hierseyn hat er das Gedicht: Die Geister des See's - aus dem diesjährigen Schillerschen Musenalmanach, als Kantate für eine Singstimme mit Begleitung des Klaviers, komponiert; auch haben wir neue Sonate für Klavier und Flöte, Quartetten u.s.w. von seiner Komposition kennen gelernt, welche unter das Vorzügliche gehören, was man in diesem Gattungen besitzt. Möchten wir durch diese wohlgemeinten Bemerkungen, die nicht etwa nur unsere, sondern Stimme des ganzen hiesigen Publikums sind, im Stande seyn, auf Herr Wölfl, die von hier nach Dresden, Berlin und Hamburg u.s.w. gehet - so viel Aufmerksamkeit zu erregen, als er verdient! Dd. Redakt”. Zob. „Allgemeine Musikalische Zeitung”, 24.04.1799, s. 479-48o. 
na flet $\mathrm{i}$ fortepian to prawdopodobnie jedna $\mathrm{z}$ trzech sonat $\mathrm{z}$ op. 11, które powstały na początku 1799 roku, a kwartety mogły pochodzić ze zbioru trzech kwartetów op. 10, które dedykował Woelfl Maricowi de Fries $^{58}$. Lipskie koncerty austriackiego kompozytora wzmiankowano raz jeszcze na łamach „Allgemeine Musikalische Zeitung”, gdzie ponownie wyrażono zadowolenie, iż jego wizyta zaowocowała dwoma koncertami, gdyż jak podaje autor, tylko nieliczni miłośnicy mogli wysłuchać pierwszego z nich. Drugi występ Woelfla zorganizowano ponoć na powszechne życzenie publiczności i dostarczył on melomanom należytej satysfakcji ${ }^{59}$. Swoją wizytę w Lipsku kompozytor wykorzystał także, by odwiedzić tam słynne wydawnictwo Breitkopf \& Härtel, co stało się początkiem wieloletniej współpracy Woelfla $\mathrm{z}$ tą oficyną ${ }^{60}$.

Kolejne kroki skierował Woelfl do Drezna, dokąd zaprosił go elektor saski Fryderyk August III. Władca znał wyciąg fortepianowy z opery Der Kopf ohne Mann i postanowił sprowadzić muzyka do swojej letniej rezydencji w Pillnitz. Także tam występ Woelfla wzbudził duże zainteresowanie. Tym razem jednak był ku temu wyjątkowy powód. Woelfl zagrał bowiem swój Koncert fortepianowy $C$-dur (tj. prawdopodobnie WoO 12b) w szczególnych warunkach. Niezbyt sprzyjająca pogoda spowodowała rozstrojenie instrumentu. Podczas próby generalnej Woelfl zorientował się, iż mimo długiego strojenia fortepian brzmi o pół tonu za nisko. Widząc gotowość całej orkiestry, postanowił podjąć się wykonania koncertu, lecz kompozycję tę przetransponował i wykonał ją w tonacji Cis-dur. „Tak oto zagrał on jeden z najtrudniejszych koncertów, z jakimi spotkałem się w życiu, w tonacji Cis-dur z taką lekkością, łatwością, dokładnością i precyzją, iż zadziwił wielce całą orkiestrę"61. Sytuacja ta, przytoczona jako anegdota na łamach „Allgemeine Musikalische Zeitung", obrazuje niezwykłą łatwość techniczną Woelfla, która pozwalała mu wykonywać bez trudu nawet najbardziej skomplikowane przebiegi. Według Baumana Woelfl nie zdobył łaski elektora i choć nie wiadomo, o jakie względy i jaką sprawę mogło tutaj chodzić, to szybki

58 M. Haider-Dechant, dz. cyt., s. 51-56.

59 "Allgemeine Musikalische Zeitung”, 29.05.1799, s. 550.

60 M. Haider-Dechant, dz. cyt., s. XXVI.

61 „Und so spielte er denn eins der schwersten Konzerte, die mit nur in meinem Leben vorgekommen sind, aus Cis dur, und mit einer Leichtigkeit, Fertikeit, Genauigkeit und Präcision, welche die ganze Kapelle in Erstaunen setzte”. Zob. „Allgemeine Musikalische Zeitung", 29.05.1799. 
wyjazd muzyka z Drezna i przybycie do Berlina już w połowie maja tegoż roku wskazywałyby na prawdziwość tej informacji ${ }^{2}$.

Pobyt w Berlinie okazał się dla Woelfla o wiele bardziej owocny. Triumfował on tam nie tylko jako wirtuoz fortepianu i zarobił tysiące talarów, ale także zjednał sobie liczne grono przyjaciół, wśród których znalazł się hrabia Camillo Marcolini, dyrektor Miśnieńskiej Manufaktury Porcelany, Akademii Sztuki oraz Zbiorów Królewskich w Dreźnie, który bawił wówczas w Berlinie ${ }^{63}$. Liczne koncerty, jakie Woelfl dawał w Berlinie, cieszyły się wysoką frekwencją, co było prawdopodobnie powodem, dla którego kompozytor pozostał w mieście przynajmniej do 2 czerwca 1799 roku, kiedy to wysłał z Berlina swój ostatni list ${ }^{64}$.

Jako kolejny cel podróży Woelfl obrał Hamburg. Po drodze odwiedził z koncertami także Szczecin oraz Ludwigslust. Do Hamburga dotarł około 2 lipca 1799 roku, kiedy to napisał kolejny list adresowany do swoich wydawców ${ }^{65}$. Hamburg był miastem lubianym przez artystów. Koncertował tam wtedy Daniel Steibelt, który przybył do Hamburga specjalnie z Londynu. Przebywali także inni, dziś bliżej nieznani artyści: pani Righini, panna Gunnet, panna Grund oraz panowie Dussart, Tieler, Marchant i Wolrabe. To z nimi planował Woelfl zorganizować wspólny koncert w Lipsku, o czym informował swojego wydawcę we wrześniu $1799 \mathrm{roku}^{66}$. 30 listopada tegoż roku odbył się ostatni koncert Woelfla w Hamburgu, po czym wraz z państwem Righini ${ }^{67}$ udał się on do Berlina i Lipska, koncertując po drodze także w Lubece.

Na długi, prawie półroczny pobyt kompozytora w Hamburgu wpływ miała z pewnością sprzyjająca artystom atmosfera miasta oraz interesujące towarzystwo. Według informacji pochodzącej od samego kompozytora właśnie ten okres przyniósł mu nowe przyjaźnie, tutaj powstał też jego portret pędzla Johanna Friedricha Tielkera. Ponadto w tym okresie Joseph Woelfl rozpoczął pracę nad swoją najnowszą

62 R. Baum, dz. cyt., s. 20.

63 W. Hitzig, dz. cyt., s. 51; cyt za: M. Haider-Dechant, dz. cyt., s. XXV.

64 Tamże.

65 R. Baum, dz. cyt., s. 20.

66 W. Hitzig, dz. cyt., s. 51; za: M. Haider-Dechant, dz. cyt., s. XXVII.

67 Mowa tutaj o Vincenzu Marii Righinim (1756-1812) oraz o jego żonie. Był to włoski kompozytor i śpiewak, od 1793 roku kapelmistrz dworu pruskiego. Zob. Ch. Henzel, Righini, Vincenzo, [w:] The New Grove Dictionary of Music and Musicians, red. S. Sadie, t. 21, London 2001, s. 385-386. 
operą Das Trojanische Pferd, o czym w grudniu 1799 roku donosiła "Allgemeine Musikalische Zeitung"68.

W Berlinie Woelfl znalazł się w grudniu 1799 roku i przebywał tam prawdopodobnie do lutego 1800 roku, kiedy to powrócił do Hamburga. W marcu 1800 roku „Allgemeine Musikalische Zeitung” odnotowała dwa kolejne koncerty kompozytora w tym hanzeatyckim mieście ${ }^{69}$. Pierwszy z nich odbył się w nieistniejącym dziś budynku ratuszowym, tzw. Eimbeckschen Haus, drugi zaś w teatrze francuskim. Woelfl wykazał się ponownie nie tylko doskonałością gry, lecz także umiejętnością komponowania i improwizowania. „Każdy pasaż, każda maniera, krótko mówiąc w s z y s t k o [podkreślenie oryg.], co on grał, wykonywał w ostatnim roku, za każdym razem czysto, dokładnie i wyraźnie"70. Woelfl miał podczas jednego $\mathrm{z}$ występów zaprezentować słuchaczom któryś z koncertów Wolfganga Amadeusa Mozarta. Autor artykułu potwierdza ponadto, że Woelfl spędził lato w Hamburgu, a następnie wyjechał z miasta razem z kapelmistrzem Righinim.

Kolejne miesiące to długa lista miast, które kompozytor zdołał odwiedzić. 27 marca 180 o roku napisał kolejny list do Breitkopfa i Härtla, donosząc tym razem, że znajduje się w Weimarze, który uznał jednak za zbyt mały do zorganizowania tam koncertu. 16 kwietnia przebywał już we Wrocławiu, gdzie nie zabawił zresztą zbyt długo. Odwiedził następnie Magdeburg, Halle, ponownie Weimar, Lipsk oraz Drezno, by przez Wrocław udać się na resztę lata do Wiednia.

Podróże Woelfl kontynuował od początku września 1800 roku. Po raz kolejny odwiedził Wrocław, Drezno, Lipsk, skąd swoje kroki skierował po raz czwarty do Berlina. Kompozytor musiał czuć się tam dobrze, był także niezwykle przychylnie odbierany przez publiczność. Jego obecność w mieście zaznaczył berliński korespondent „Allgemeine Musikalische Zeitung", tworząc raport o stanie muzycznym miasta Ueber den Zustand der Musik in Berlin, während des Winters im gegenwärtigen Jahre ${ }^{71}$. Wspomniał tam berlińskie występy Woelfla, które przyciągały słuchaczy ze wszystkich stanów społecznych. Ponadto pismo zwróciło uwagę także na jego bieżącą działalność koncertową,

68 „Allgemeine Musikalische Zeitung”, 25.12.1799, s. 238.

69 "Allgemeine Musikalische Zeitung”, 5.03.1800, s. 408.

70 „Jede Passage, jede Manier, kurz a ll e s, was er spielen unternahm, brachte er, selbst noch in seinen letzten Lebenjahren, jedes Mal durchaus rein, bestimmt und deutlich heraus". Zob. tamże.

71 „Allgemeine Musikalische Zeitung”, 28.05.180o, s. 618-623. 
opisując ją szeroko na łamach styczniowego numeru. Anonimowy autor wspomniał w nim występ Woelfla z 10 grudnia 1800 roku, kiedy wykonano symfonię w tonacji G-dur Josepha Haydna oraz koncert podwójny na skrzypce i fortepian Woelfla (tj. prawdopodobnie WoO 24). Dzieło to stworzył kompozytor, zdaje się, podczas letniego pobytu w Wiedniu. W Berlinie wykonał je z niejakim Seidlerem:

Koncertowanie było nowe i żywe, częściowo także pięknie przygotowane i przez solistów wykonane bardzo czysto. Nie podobały mi się jednak ritornelle, [...] były one ciągle przerywane przez obojowe i fagotowe tyrady, podczas gdy ritornelle w koncercie powinny stanowić jedność i tworzyć spójną całość. O wiele pochlebniej oceniono solowy popis improwizatorski pianisty: Pan Wölfl zaprezentował muzyczny żart. [...] Wölfl pokazał się przy tym jako szczególny pianista, jako człowiek przewyższający innych sobie podobnych. Jego gotowość, swoboda i lekkość zadziwiają, a jego dokładność, opanowanie i krągłość, z jakimi wszystko wykonuje, a co dla innej ręki byłoby trudne, zapewniają mu należyty hołd. Nie gra on nic, co nie byłoby bardzo trudne, wszystko jednak brzmi tam niezwykle łatwo. Dla tego wyjątkowego pianisty nic z tego co wyobraźnia przekazuje rękom, nie jest niemożliwe, a cały swój talent chce poświęcić prawdzie i pięknu. [...] Wariacje były bardzo przyjemne, a improwizacja, jak już wspomniałem, pełna była nowych myśli, których nie spotyka się na co dzień72.

Wiadomo zatem, że Woelfl z sukcesem improwizował. Lekkość i swoboda, z jaką to czynił, świadczą o jego olbrzymiej wyobraźni muzycznej oraz często już wspominanej łatwości technicznej.

72 „Die Ritornelle gefielen mir nicht, weil sie [...] durch eine Menge kleiner Tiraden der Oboen und Fagotten beständig unterbrochen werden, anstatt dass die Ritornelle in einem Konzert gerade in zusammenhängenden Massen bestehen müssen, aus welchen das Einzelne ausgeht. Nach diesem hatte Herr Wölfl eine musikalische Badinage angekündigt. [...] Wölfl zeigte dabey besonders als Fortepianospieler, als einen Mann von entschiedenem Uebergewicht über die meisten seines Gleichen. Seine Fertigkeit, Freyheit und Leichtigkeit ist bewunderswürdig, und die Deutlichkeit, Haltung und Rundung, mit der alles klar dasteht, was für jede andere Hand schwer ist, müssen ihm bey den Besten Gleichen Ehre bringen. Er spielt beynahe nichts, das nicht sehr schwer wäre und doch klingt alles leicht. Wenn dieser ausserordentliche Klavierspieler jetzt, da ihm fast nichts mehr unmöglich ist, was die Phantasie der Hand übergeben kann, sein ganzes Talent der Wahrheit und Schönheit weihen wollte; [...] Die Variationen waren übrigens allerliebst und Phantasie, wie schon gesagt, voller neuen Gedanken, die nicht alle Tage kommen”. Zob. „Allgemeine Musikalische Zeitung”, 1.01.1801, s. 237. 
Berlińskie sukcesy przerwał krótki wyjazd do Lipska, gdzie Woelfl koncertował w grudniu 1800 roku. Także tam prezentował się jako doskonały pianista oraz improwizator. Do Berlina wrócił jednak już w styczniu 1801 roku i dwudziestego trzeciego dnia tego miesiąca grał razem $z$ Friedrichem Heinrichem Himmelem ${ }^{73}$. Muzycy mieli wówczas wykonać jakąś podwójną sonatę fortepianową, prawdopodobnie Grande Sonata in C-dur Himmla. Warto zaznaczyć, że to właśnie temu artyście Woelfl poświęcił swój skomponowany niedługo później w Paryżu Koncert fortepianowy G-dur op. 20.

Znaczną część roku 1801 Woelfl spędził w Hamburgu, dokąd jechał przez Brunszwik, Kassel, Frankfurt nad Menem, Moguncję, Koblencję, Trewir i Metz. W marcu 1801 roku pisał do swoich lipskich wydawców, informując ich o swym pobycie w Brunszwiku i planach podróży do Hanoweru. To właśnie z Hanoweru w kwietniu 1801 roku wysłał list, w którym doniósł o swoich dalszych planach wyjazdu do Paryża oraz Londynu, gdzie przyszło mu spędzić ostatnie lata swojego życia ${ }^{74}$. W maju Woelfl udał się w dalsze podróże koncertowe. Tym razem za swój cel obrał Frankfurt nad Menem, Offenbach oraz Darmstadt.

Woelfl zyskiwał coraz większą sławę. Był ceniony jako wybitny wirtuoz fortepianu oraz kompozytor. W opublikowanym na łamach „Allgemeine Musikalische Zeitung” w lipcu 1801 roku artykule zatytułowanym Briefe über Tonkunst und Tonkünstler opisano sylwetki wybitnych pianistów epoki. Anonimowy korespondent porównuje tam dokonania niemieckiego pianisty i kompozytora Friedricha Heinricha Himmela, Czecha Jana Ladislava Dusska oraz Josepha Woelfla, konkludując, iż palmę pierwszeństwa należy przyznać ostatniemu z nich ${ }^{75}$.

Jesienią 1801 roku kompozytor opuścił Niemcy. Podsumowaniem jego dotychczasowych osiągnięć może być krótka recenzja opublikowana w lipcu tegoż roku na łamach „Allgemeine Musikalische Zeitung” po ostatnim hanowerskim koncercie pianisty: „Pan Wölfl koncertował tutaj przy niesłabnącym aplauzie i wielkim zainteresowaniu nie tylko miłośników muzyki, ale także osób zajmujących się nią zawodowo. Teraz zaś udaje się on do Paryża"76.

73 M. Haider-Dechant, dz. cyt., s. XXX.

74 W. Hitzig, dz. cyt., s. 53; za: M. Haider-Dechant, dz. cyt., s. XXX.

75 „Allgemeine Musikalische Zeitung”, 3.06.1801, s. 608-610.

76 „Herr Wölfl hat hier mit vielem Beyfall und anständiger Unterstützung verschiedene Konzerte gegeben, was um desto mehr bemerkt zu werden verdient, da es uns zwar an Personen, die Musikliebhaber seyn wollen, im geringsten nicht fehlt, 


\section{Paryż (1801-1805)}

Do Paryża Woelfl przybył jesienią 1801 roku, choć jego sława dotarła do Francji już dużo wcześniej. Potwierdza to notka prasowa z „Journal de Paris" z października 1801 roku, w której Woelfl został przedstawiony jako sławny i długo oczekiwany przez francuskich melomanów pianista $^{77}$. Ceniony był tam przede wszystkim za umiejętność improwizacji i opisany jako niemiecki cud ${ }^{78}$. Bardzo szybko wkroczył w koncertowy świat Paryża. Między 6 a 14 lutego 1802 roku „Journal de Paris” aż osiem razy zapowiadał jego pierwszy występ w tym mieście ${ }^{79}$. Na podstawie opublikowanego tam programu wiemy, że spośród dzieł Woelfla zabrzmiał wówczas koncert fortepianowy (tj. prawdopodobnie Koncert G-dur op. 20), wariacje na fortepian oraz że wieczór zakończył się improwizacją pianisty. Obok jego utworów wykonywano także dzieła Josepha Haydna, Giovanniego Paisiella i Domenica Cimarosy.

O paryskich sukcesach Woelfla donosiła także prasa polska. W jednym z numerów „Gazety Warszawskiej” z sierpnia 1802 roku paryski korespondent zamieścił notkę prasową następującej treści:

Mamy tu teraz 2ch z pomiędzy najsławnieyszych kompozytorów oper, Jozefa Woelfl (ten był dawniey przez kilka miesięcy w Warszawie i wszystkim amatorom muzyki dobrze iest znaiomy) i P. Winter. Pierwszy bawi się tu ciągle i układa teraz operę dla teatru „Feydeau"; przedsięwziął niedawno podróż do Leodium i Spa [Liège i Spa - miejscowości w dzisiejszej Belgii], lecz wkrótce powróci. Nadzwyczayna jego letkość i szypkość [sic] w graniu na fortepiano, powszechnie podziwienie sprawia i między naypierwszych wirtuozow mieścić go każe ${ }^{80}$.

O podpisanym z teatrem Feydeau kontrakcie pisze też sam kompozytor w swoim liście do lipskich wydawców: „dostałem kontrakt w teatrze Feydan [sic]. [...] kilka razy już tu grałem i odnosiłem ogromne sukcesy"si.

aber an Personen, die für Musik etwas thäten, desto mehr. Herr W. wird nach Paris gehen”. Zob. „Allgemeine Musikalische Zeitung”, 8.07.1801, s. 690.

77 Por. M. Haider-Dechant, dz. cyt., s. XXX.

78 "Allgemeine Musikalische Zeitung”, 20.02.1802, s. 324.

79 "Journal de Paris", 6-14.02.1802, s. 824, 866.

80 "Gazeta Warszawska” (dodatek), 3.08.1802, s. 152. Pisownia oryginalna.

81 „Ich habe den Auftrag für das Theater Feydan [sic] zu arbeiten. [...] ich habe hier ein paarmal öffentlich gespielt und vielen Beifall bekommen". Cyt. za: W. Hitzig, dz. cyt., s. 57. 
Jesienią 1802 roku Woelfl opuścił na krótko Paryż i udał się w podróż do Holandii i Anglii. Pierwszym znanym nam dziś celem podróży był Amsterdam, gdzie muzyk dał koncert. Fakt ten wspomina krótko "Allgemeine Musikalische Zeitung”: „Pan Wölfl, który przybył do Amsterdamu z Paryża, wystąpił tu przy wielkim aplauzie publiczności, stąd jedzie on do Londynu"82. Wojenne zawirowania spowodowały jednak, że muzyk musiał przesunąć swoją podróż do Anglii. Pocieszeniem były z pewnością niezwykle wysokie sumy, jakie zarobił w Holandii, więc przez Lille powrócił znów do Paryża ${ }^{83}$. Nieustającym sukcesom koncertowym Austriaka towarzyszyły nowo wydane kompozycje. Publikację jego utworów gazeta "Cocatrix" zapowiadała obok dzieł Mozarta i Beethovena ${ }^{84}$.

Obok licznych dzieł na fortepian Woelfl ukończył i opublikował wówczas swoje najnowsze dzieło operowe. W październiku 1803 roku redaktor „Allgemeine Musikalische Zeitung” pisał: „Już się cieszę, że możemy się spodziewać nowej opery Woelfla w Teatrze Feydeau" ${ }^{85}$. Mowa tu zapewne o jednoaktówce komicznej pt. L’amour romanesque, w katalogu dzieł kompozytora oznaczonej jako $\mathrm{WoO}_{35}$, której premiera odbyła się 3 marca 1804 roku $^{86}$. Pierwsze wykonanie utworu było dość długo wyczekiwane i zapowiadane przez szereg francuskich gazet, m.in. „Courrier des Spectacles” czy „Journal de Paris”, operę komentowała także prasa zagraniczna. „Allgemeine $\mathrm{Mu}-$ sikalische Zeitung" doniosła ponadto o premierze kolejnego koncertu fortepianowego Woelfla, tj. II Koncertu op. 26. Paryski korespondent ocenił koncert jako najlepszy z jego dotychczasowych dzieł, pisząc: „Koncert wybornie napisany, tak błyskotliwie i żywo, nowatorsko, ale też mniej osobliwie od jego wcześniejszych utworów"87.

82 „Hr. Wölfl, der von Paris nach Amsterdam gereiset war, liess sich daselbst mit vielem Beyfall hören, und gehet nun von da nach London”. Zob. „Allgemeine Musikalische Zeitung", 10.11.1802, s. 115.

83 W. Hitizg, dz. cyt., s. 59-60.

84 "Cocatrix”, 8.10.1803.

85 "Ich höre, wir haben von Woelfl eine neue Oper auf dem Theater Feydeau zu erwarten, und ich freue mich darauf”. Zob. „Allgemeine Musikalische Zeitung”, 21.10 .1803 , s. 865 .

86 M. Haider-Dechant, dz. cyt., s. 273.

87 „Ein neues Konzert von seiner Komposition auf dem Pianoforte. Das Konz. war trefflich geschrieben, wenigstens eben so geistreich, lebhaft, neu und gut durchgeführt, aber weniger bizarr, als frühere von ihm”. Zob. „Allgemeine Musikalische Zeitung", 28.11.1804, s. 713. 
Pod koniec swojej paryskiej działalności Woelfl znów powrócił do twórczości operowej, tworząc tym razem olbrzymie dzieło heroiczne w trzech aktach Fernand, ou les Maures, w katalogu dzieł kompozytora oznaczone jako WoO $35^{88}$. Wystawione 11 lutego 1805 roku w Opéra Comique, musiało nieco zaskoczyć ówczesną publiczność. Niezbyt pochlebne recenzje prasowe krytykują co prawda nie tyle samą kompozycję, ile reżyserię oraz śpiewaków ${ }^{89}$. Klęska dzieła w Paryżu spowodowała jednak niechęć Woelfla do gatunku opery na dłuższy czas.

Paryski czas w życiu Woelfla zaowocował za to szerokimi kontaktami z najważniejszymi muzykami Europy oraz z melomanami i przedstawicielami najwyższej klasy społecznej. Woelfl wydał tam szereg nowych dzieł i zyskał ogromną sławę, która przekroczyła granice Francji i z pewnością ułatwiła mu dalszy podbój Europy.

\section{Londyn (1805-1812)}

Woelfl pojawił się w Londynie wiosną 1805 roku, witany jako słynny pianista i kompozytor. Już 25 maja 1805 roku gazeta „The Morning Chronicle" zapowiedziała jego pierwszy występ, podczas corocznego koncertu benefisowego u państwa Ashéów, podkreślając, że: „pan Woelff [sic], który właśnie przybył do Londynu, zagra swój koncert na wielkim piano-forte" ${ }^{90}$. Koncert odbył się 27 maja 1805 roku.

Niedługo londyńczycy czekali na kolejny występ Austriaka. Kilka dni później ta sama gazeta zapowiedziała występ muzyka podczas koncertu państwa Ashley’ów: „koniec pierwszej części wieczoru stanowić będzie koncert na fortepianie słynnego pana Woelfla, będący jego pierwszym publicznym występem w tym kraju"91. Warto dodać, że występ ten odbył się w teatrze Covent Garden.

88 M. Haider-Dechant, dz. cyt., s. 287-291.

89 „Allgemeine Musikalische Zeitung”, 27.03.1805, s. 421.

90 „Mr.Woelff [sic], who is just arrived in England, will perform a Concerto on the Grand Piano-forte”. Zob. „The Morning Chronicle”, 25.05.1805.

91 "End of Part I a Concerto on the Grand Piano Forte, by the celebrated Mr. Woelfle, being his first public appearance in this country”. „The Morning Chronicle”, 1.06.1805, s. 244 . 


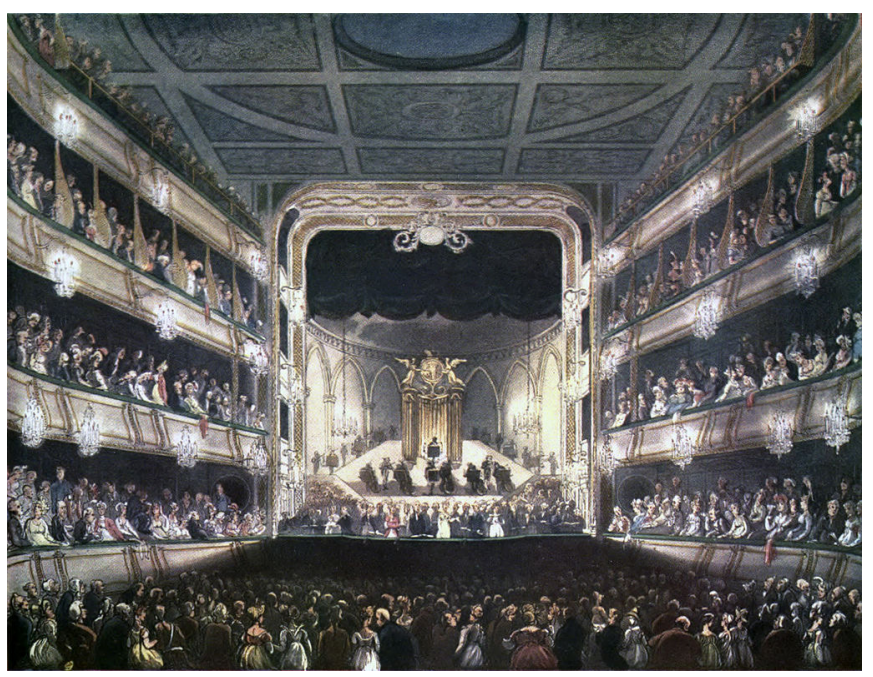

Ilustracja 3. Wnętrze teatru Covent Garden. Źródło: R. Ackremann i in., Microcosm of London, London 1810, il. 100.

Niezwykła gra Austriaka wywierała na angielskiej publiczności wrażenie. Znamienny przykład stanowi list z 25 stycznia 1806 roku autorstwa londyńskiej pisarki Hester Lynch Piozzi, która opisuje, jak wielkie wrażenie wywarła na nim niezwykle wirtuozowska gra Josepha Woelfla.

Zeszłej nocy widzieliśmy mężczyznę, którego perfekcja jest olśniewająca, wyglądał wręcz, jakby poświęcił wszystko nauce - saksoński pianista, który oszołomił nasze małe grono znawców - które w pełni zgodziło się co do jego niewątpliwej wyższości nad wszystkimi dotąd nam przedstawionymi. Rauzzini, Piozzi, Neild; pani Parkes, pani Sharp i jeszcze pół tuzina więcej kompetentnych słuchaczy wyraziło swój entuzjastyczny podziw dla jego siły, która zaparła mi dech i sprawiła, że wróciłam do domu wyczerpana, jakbym to ja grała lekcję przed samą sobą. Wolfen czy Wolveren brzmi jego nazwisko ${ }^{92}$.

92 „We saw a Man last Night whose Perfections are of the most dazzling kind, he looked like one indeed who had sacrificed all to Study - A Saxon Performer on the Piano e forte who so amazed our little Custer of Knowing-ones - that all agreed on his undoubted Superiority to every thing yest exhibited. Rauzzini, Piozzi, Neild; Miss Parkes, Miss Sharp and half an Dozen more competent Auditors expressed their Rapturous Wonder at his Powers, which really put me completely out of 
Obok niezwykle owocnej działalności koncertowej austriacki pianista kontynuował swoją pracę twórczą. W listopadzie 1805 roku przygotował pierwszą premierę większego dzieła, tj. baletu Terpsichores Return, który wystawiono w teatrze Drury Lane 1 listopada 1805 roku. Niedługo później muzyka Woelfla zabrzmiała w King’s Theatre, gdy 7 grudnia 1807 roku z okazji ponownego otwarcia teatru po jego remoncie, wystawiono tam operę Petera von Wintera Il Ratto di Proserpina oraz balet Naval Victory and Triumph of Lord Nelson z muzyką Josepha Woelfla ${ }^{93}$.

Na początku 1806 roku Woelfl odniósł kolejny sukces kompozytorski, tym razem swoim koncertem fortepianowym Le Calm op. 36. Londyńska prasa regularnie donosiła o poczynaniach mistrza, dzięki czemu łatwo obliczyć, że koncert ten tylko w 1806 roku wykonał on pięciokrotnie ${ }^{94}$. W maju 1806 występował średnio trzy razy w tygodniu. 8 maja zaprezentowano jego nową symfonię i duet na fortepian oraz harfę, który wraz z Woelflem wykonał słynny harfista i kompozytor François Joseph Dizi ${ }^{95}$. Wspólnie z Dizim święcił Woelfl także jeden ze swych ważniejszych londyńskich sukcesów, jakim był występ podczas słynnych koncertów Salomona, na których w przeszłości wykonywano m.in. symfonie londyńskie Josepha Haydna. U Salomona Woelfl wystąpił 20 czerwca 1806 roku, kiedy wykonał wraz z Dizim swój kolejny, dedykowany właśnie Salomonowi duet na fortepian i harfę op. $37^{96}$.

Podsumowaniem pierwszych dwóch niezwykle owocnych lat londyńskiej działalności Woelfla może stać się zbiór dzieł wydany w 1806 roku w oficynie Vogla dla angielskiego przedsiębiorcy i menadżera niemieckiego teatru w Londynie - Fredericka Schirmera ${ }^{97}$. Zbiór zawiera utwory wybrane przez Schirmera. Znamienny jest wpis na karcie tytułowej tomu, gdzie na życzenie Schirmera wpisano jedno tylko nazwisko, mimo że tom obejmuje utwory i aranżacje wielu muzyków: „Praca zawiera ulubione arie z najsłynniejszych niemieckich

Breath, and sent me home fatigued as if I had been playing the Lesson over Myself. Wolfen or Wolveren is his Name". Zob. H.L. Piozzi, The Piozzi Letters: The Correspondence of Hester Lynch Piozzi, 1784-1821 (formerly Mrs. Thrale), red. E.A. Bloom, L.D. Bloom, London, 1989-2002, t. 4, s. 95; cyt. za: R. Redgewell, Joseph Woelfl in England, [w:] „Joseph Woelfl-Almanach”, dz. cyt., s. 73.

93 „The Times”, 6.12.1805.

94 M. Haider-Dechant, dz. cyt., s.106-110.

95 „The Times”, 7.05.1806.

96 M. Haider-Dechant, dz. cyt., s. 112.

97 Tamże, s. 304-305. 
oper i inne muzyczne dzieła, zaaranżowane, a częściowo oryginalnie skomponowane na fortepian lub harfę przez pana Woelfla i najsłynniejszych muzyków kontynentu". Zbiór ten w katalogu dzieł kompozytora autorstwa Margit Haider-Dechant odnaleźć można pod numerem $\mathrm{WoO} 42^{98}$.

Ostatni znany nam list kompozytora do lipskich wydawców Breitkopfa i Härtla potwierdza powodzenie zawodowe, a co za tym idzie, finansowe muzyka, który pisał:

Wkrótce ukaże się znaczna liczba moich małych rzeczy, które zostaną wydane jako dzieło zatytułowane le bouquet de Flor... mam ciągle wiele pracy, a moje stawki, zarówno za udzielanie lekcji, jak i za kompozycje, są najwyższe wśród tutaj obowiązujących. W języku angielskim jestem na tyle mocny, że wszystkie moje interesy mogę w nim załatwić. Można sobie łatwo wyobrazić, że nie ma tutaj tyle przyjemności, co w Paryżu czy Wiedniu, są za to pieniądze, a to zawsze jest rzeczą dobrą. Sprawi mi Pan wielką przysługę, jeśli się Pan dowie u któregoś frankfurtczyka, czy moja żona jest tam jeszcze. Już długo nie dostałem od niej żadnego listu... Pana najuniżeńszy przyjaciel J. Woelf999.

Cytowane słowa obrazują zadowolenie muzyka z jego pozycji na londyńskim rynku, przedstawiają także nieco skomplikowaną sytuację rodzinną. Regularnie kontaktował się on za to z niemieckojęzycznym światem muzycznym, przede wszystkim wydawniczym. Oficyna Breitkopf \& Härtel wciąż wydawała jego dzieła, wspominała o nim także niemieckojęzyczna prasa.

98 "The work to contain the best favourite songs of the most celebrated German Operas and other musical pieces, arranged and partly originally composed for the Piano-forte, or the Harp, by Mr. WCELFL and the most celebrated masters on the Continent"; cyt. za: M. Haider-Dechant, dz. cyt., s. 304-305.

99 „Bringe in Kurzem eine ziemliche Anzahl kleiner Dinge heraus welche in einem periodischen Werke, le bouquet de Flor nummernweise erscheinen sollen... ich habe immer sehr viel zu tun und meine Preise sowohl im Lectiongeben wie in der Komposition sind die höchsten, die man hier macht. Daher bin ich immer sehr vergnügt und unterhalte mich so gut ich kann. Der engl[ischen] Sprache bin ich soweit mächtig, daß ich alle meine Geschäfte damit ordentlich besorgen kann. $\mathrm{Daß}$ man hier nicht soviel Vergnügen hat wie in Paris oder Wien, können Sie sich leicht vorstellen, dafür gibt es aber Geld, was immer eine gute Sache ist. Sie würden mir einen großen Gefallen tun, wenn Sie sich bei einem Frankfurter erkundigten, ob meine Frau noch dort ist, ich habe schon seit langer Zeit keine Briefe von ihr bekommen... Ihr ergebenster Freund J. Woelfl”. Cyt. za: W. Hitzig, dz. cyt., s. 61. 
Obok działalności koncertowej oraz kompozytorskiej Woelfl dawał $\mathrm{w}$ Londynie lekcje gry na fortepianie $\mathrm{i}$, jak sam pisał w cytowanym liście do wydawców, miał stawki „najwyższe”. Wśród jego uczniów największą sławę zyskał Anglik - Cipriani Potter, od 1832 roku dyrektor Royal Academy of Music ${ }^{100}$.

Za szczytowy punkt londyńskiej kariery Austriaka Rupert Ridgewell uznaje rok 1808, gdy 25 kwietnia w King's Theater odbył się koncert benefisowy Woelfla. Program koncertu dwa dni wcześniej ogłosił „The Times” ${ }^{101}$.Widnieją w nim 4 kompozycje samego Woelfla Grand Overture, Piano Sonata, Grand Symphony (tj. prawdopodobnie Symfonia D-dur op. 45) oraz duet na fortepian i harfę. Obok Woelfla podczas koncertu wystąpiło dwóch śpiewaków - bas Giuseppe Naldi oraz tenor John Braham. Zastanawia fakt, że londyńska prasa zapowiedziała wprawdzie wydarzenie, nie zamieściła jednak komentarzy i krytyk po koncercie benefisowym. Nie wiadomo zatem, jak został on przyjęty i czy w ogóle się odbył. Rupert Ridgewell zauważa ponadto, że od tego momentu Woelfl coraz rzadziej występował jako pianista ${ }^{102}$. Rok później, w kwietniu 1809 roku, odbyła się premiera kolejnego koncertu fortepianowego Le Coucou op. 49. Tym razem to nie kompozytor zasiadł do fortepianu, lecz niejaka pani Ferrari, której koncert był dedykowany ${ }^{103}$.

Prasa angielska dostarcza nam stosunkowo niewiele informacji dotyczących dwóch ostatnich lat życia Josepha Woelfla. W 1810 roku Austriak przygotował do wydania interesujący, autorski zbiór własnych utworów, zatytułowany Harmonic Budget, w katalogu dzieł kompozytora oznaczony WoO $63^{104}$. Antologia ta stanowi interesujący przekrój twórczości pieśniowej, utworów fortepianowych na dwie i cztery ręce, a także kompozycji kameralnych przeznaczonych na różne obsady instrumentalne. Warto dodać, że wszystkie zawarte w Harmonic Budget

100 Cipriani Potter (1792-1871) - angielski pianista, kompozytor oraz pedagog. Od 1822 roku zatrudniony w londyńskiej Royal Academy of Music, gdzie prowadził orkiestrę. Pozostawił po sobie liczne utwory na fortepian solo, utwory kameralne oraz symfoniczne, w tym trzy koncerty fortepianowe. Zob. P.H. Peter, J. Rushton, Potter (Philip) Cipriani, [w:] The New Grove Dictionary of Music and Musicians, red. S. Sadie, t. 20, London 1980, s. 221-223.

101 „The Times”, 23.04.1808.

102 R. Ridgewell, Joseph Woelfl in England, „Joseph Woelfl Almanach” 2012/2013, s. 74 .

103 M. Haider-Dechant, dz. cyt., s. 152-154.

104 Tamże, s. 346. 
utwory opatrzył Woelfl precyzyjnymi oznaczeniami agogicznymi. Wykorzystał w tym celu najnowsze osiągnięcie tamtego czasu - tzn. tempo pendulum (prototyp metronomu).

W 1811 roku Woelfl ponownie zaznaczył się swoją działalnością w koncertowym życiu miasta. Londyńska publiczność miała szansę poznać jego najnowsze dzieło symfoniczne. 8 lutego podczas koncertu pani Tibb zabrzmiała Grand Symphony, tj. prawdopodobnie WoO 127, której wykonaniem zza fortepianu kierował sam kompozytor ${ }^{105}$. Niewiele później, w marcu tegoż roku podczas wieczoru New Musical Fund w King's Theatre symfonia Woelfla zabrzmiała ponownie, tym razem wykonanie poprowadził sir George Smart ${ }^{106}$.

Nie bez znaczenia są muzyczne kontakty Josepha Woelfla w Londynie. Bardzo szybko stał się tam ważnym uczestnikiem najistotniejszych wydarzeń świata muzyki. Występował dla najwyższych klas społecznych i ze znamienitymi artystami. Regularnie współpracował m.in. $z$ Johannem Peterem Salomonem, najważniejszym impresariem Londynu. 16 maja 1812 roku zabrzmiał u niego ostatni Koncert fortepianowy E-dur op. 64 Josepha Woelfla. Za fortepianem zasiadła niejaka panna Cudmore.

Niedługo po tym wydarzeniu londyńska „The Morning Chronicle” zamieściła informację o śmierci kompozytora: „We wtorek rano, po krótkiej chorobie, w swoim mieszkaniu na Great Mary-le-bone Street zmarł słynny pianista Mr. Woelfl"107. Joseph Woelfl zmarł 21 maja 1812 roku.

\section{Zakończenie}

Urodzony w 1773 roku w Salzburgu kompozytor Joseph Woelfl swoją muzyczną edukację rozpoczął w rodzinnym mieście. Wykształcony w tamtejszej szkole Kapellhaus, pobierał także prywatne lekcje w domu rodziny Mozartów. W 1790 roku opuścił Salzburg i wyruszył do Wiednia. Rok później otrzymał posadę w Guzowie koło Żyrardowa u ojca stylizowanego poloneza - księcia Michała Kleofasa Ogińskiego,

105 "The Times", 8.02.1811.

106 „The Times", 28.03.1811.

107 „DIED. On Thursday morning, after a short illness, at his lodging in Great Mary-le-bone-street, Mr. Woelfl, the celebrated Piano Forte Player”. Cyt. za: „The Morning Chronicle", 23.05.1812. 
w służbie którego spędził około piętnastu miesięcy. W 1792 roku Woelfl opuścił dwór Ogińskich i udzielał w Warszawie lekcji gry na fortepianie oraz co najmniej dwa razy wystąpił publicznie. Wiadomo też, że w 1793 roku koncertował w Grodnie podczas obrad sejmowych z udziałem króla. Już w 1795 roku przebywał znów w Wiedniu, gdzie powstał szereg jego dzieł kameralnych - sonat na fortepian solo, na fortepian i skrzypce oraz kwartet smyczkowy, a także liczne dzieła operowe. W latach 1799-1801 kompozytor poświęcił się głównie podróżom po Niemczech, podczas których zachwycał publiczność swoją wirtuozowską grą na fortepianie. Gdy w 1801 roku Woelfl przybył do Paryża, był tam już dobrze znany i z łatwością odnalazł się w tamtejszym środowisku muzycznym, a jego paryskie osiągnięcia koncertowe były wielokrotnie wzmiankowane przez prasę francuską oraz zagraniczną. W pierwszych latach pobytu w Paryżu opublikował szereg opusów swoich kompozycji, m.in. op. 14-20, które zawierały głównie sonaty na fortepian solo oraz na dwa fortepiany, sonaty triowe, a także omawiany tu I Koncert fortepianowy. Nie jest jednak wykluczone, że część $\mathrm{z}$ tych dzieł powstała jeszcze przed przyjazdem muzyka do Paryża. W 1805 roku Woelfl dotarł do Londynu, gdzie spędził resztę życia. Był tam niezwykle cenionym przedstawicielem świata muzycznego oraz nauczycielem fortepianu. Zmarł 21 maja 1812 roku.

W swoim dorobku kompozytorskim Woelfl pozostawił cały szereg dzieł reprezentujących różne gatunki muzyczne, tj. pieśni, utwory wokalno-instrumentalne, sceniczne, wielkie formy instrumentalne, koncerty solowe oraz kameralne, szereg dzieł kameralnych - duety, tria, kwartety oraz kwintety, a przede wszystkim liczne utwory fortepianowe - sonaty, wariacje, tańce, opracowania fragmentów operowych własnego lub obcego autorstwa, utwory na cztery ręce oraz pedagogiczne. Warto dodać, iż pod koniec życia Woelfl stworzył także rodzaj szkoły na fortepian - Practical School for the Piano Forte op. 56, $\mathrm{w}$ dwóch tomach zawierających w sumie pięćdziesiąt ćwiczeń.

Jeszcze w 1815 roku jedną z symfonii Woelfla wykonano podczas koncertów Salomona, a Giovanni Battista Viotti zadyrygował wykonaniem uwertury orkiestrowej Woelfla. Po utwory Woelfla sięgali też jego uczniowie, m.in. Cipriani Potter. Niestety wkrótce po śmierci kompozytora jego twórczość została prawie zupełnie zapomniana.

Dziś jego ogromnie interesujące i wartościowe artystycznie dzieła przywracane są do życia koncertowego, głównie dzięki niespożytej energii Margit Haider-Dechant, która nie tylko propaguje je jako 
pianistka, ale też sporządziła ich katalog tematyczny, założyła Joseph Woelfl Gesellschaft i Dom Woelfla w Bonn oraz organizuje poświęcone kompozytorowi sympozja naukowe - Internationale Joseph Woelfl Symposium (czwarte z nich odbyło się w Bonn w kwietniu 2018 roku ${ }^{108}$. W działającej przy Joseph Woelfl Gesellschaft oficynie wydawniczej Apollon Musikoffizin publikowane są także tomy pokonferencyjne pod redakcją Margit Haider-Dechant oraz Hermanna Dechant („Joseph Woelfl-Almanach” 2012/2013, 2014/2015 oraz 2016/2017), a także drukowane nowe wydania dzieł kompozytora.

\section{Bibliografia}

\section{Książki i artykuły}

Baird O., Joseph Woelfl in Warsaw: His Polish Patrons, Pupils, Addressees and Friends, „The Musical Times” 159 (2018), nr 1948.

Baum R., Joseph Wölfl (1773-1812). Leben, Klavierwerke, Klavierkammermusik und Klavierkonzerte, Kassel 1928.

Beethoven aus der Sicht seiner Zeitgenossen in Tagebücher, Briefen, Gedichten und Erinnerungen, red. K.M. Kopitz, R. Ladenbach, t. 1, München 2009.

Bernacki L., Teatr, dramat i muzyka za Stanisława Augusta, t. 1, Źródła i materiały, Warszawa 1979.

Chybiński A., Woelffl Joseph [w:] Słownik muzyków dawnej Polski do roku 180o, Kraków 1949.

Eitner R., Woelfl Joseph [w:] tenże, Biographisch-Bibliographisches Quellen-Lexikon der Musiker und Musikgelehrten, t. 10, Leipzig 1904.

Feicht H., Musikalische Beziehungen zwischen Wien und Warschau, „Studien zur Musikwissenschaft” 25 (1962).

Haider-Dechant M., Joseph Woelfl. Verzeichnis seiner Werke, Wien 2011. Haider-Dechant M., Wölfl Joseph, [w:] Die Musik in Geschichte und Gegenwart. Personenteil, red. L. Finscher, t. 17, Kassel 2007.

Haman H.W., Wölfl Joseph, [w:] The New Grove Dictionary of Music and Musicians, red. S. Sadie, t. 20, London 1980.

Hitzig W., Die Briefe Joseph Wölfls an Breitkopf \& Härtel, [w:] Jahrbuch von Breitkopf u. Härtel auf das Jahr 1926, Leipzig 1926.

108 Zob. Woelfl-Haus Bonn, https://sites.google.com/view/joseph-woelfl-gesellschaft-eng/joseph-woelfl [dostęp: 27.02.2018]. 
Jędrychowski Z., Teatra grodzieńskie 1784-1864, Warszawa 2012.

„Joseph Woelfl-Almanach” 2012/2013, red. M. Haider-Dechant, H. Dechant.

Mozart. Briefe und Aufzeichnungen, Gesamtausgabe, red. Wilhelm A. Bauer, O.E. Deutsch, [b.m.] 1962; wyd. uzup., red. K. Urlich, Kassel 2005.

Ogiński M.K., Listy o muzyce, oprac. T. Strumiłło, Kraków 1956.

Partyk M., Wölfl Joseph, [w:] Encyklopedia muzyki PWM. Część biograficzna, red. E. Dziębowska, t. 12 (W-Ż), Kraków 2012.

Schmid M.H., Eder P., Mozart in Salzburg. Ein Ort für sein Talent, Salzburg 2006.

Schurig A., Wolfgang Amadeus Mozart. Sein Leben und sein Werk auf Grund der vornehmlich durch Nikolaus von Nissen gesammelten biographischen Quellen und der Ergebnisse der neuesten Forschung dargestellt, Leipzig 1913.

Srb M.M., Joseph Wölfl, sein Leben und seine Instrumentalwerke. Mit besonderer Berücksichtigung seiner Klavierwerke, praca doktorska, Universität Wien, Wien 1930 (Universitätsbibliothek Wien, sygn. D 2286).

West E., Woelfl Joseph, [w:] The New Grove Dictionary of Music and Musicians, red. S. Sadie, t. 27, London 2001.

Źórawska-Witkowska A., Muzyka na dworze i $w$ teatrze Stanisława Augusta, Warszawa 1995.

\section{Źródła prasowe}

"Allgemeine Musikalische Zeitung”: 24.03.1799, 24.04.1799, 15.05.1799, 29.05.1799, 24.04.1799, 29.05.1799, 25.12.1799, 5.03.1800, 28.05.1800, 1.01.1801, 3.06.1801, 8.07.1801, 20.02.1802, 21.10.1803, 28.11.1804, 9.12.1804, 27.03.1805, 8.06.1807, 7.12.1811.

"Journal de Paris": 11.10.1801.

"Cocatrix": 8.10.1803.

"Gazeta Warszawska”: dodatek, 3.12.1802.

„The Morning Chronicle": 25.05.1805, 1.06.1805, 23.05.1812.

„The Times”: 6.12.1805, 7.05.1806, 23.04.1808, 8.02.1811, 28.03.1811. 